IZA DP No. 8071

Roadblocks on the Road to Grandma's House: Fertility Consequences of Delayed Retirement

Erich Battistin

Michele De Nadai

Mario Padula

March 2014 


\title{
Roadblocks on the Road to Grandma's House: Fertility Consequences of Delayed Retirement
}

\author{
Erich Battistin \\ Queen Mary University, \\ IRVAPP and IZA \\ Michele De Nadai \\ University of Padova \\ Mario Padula \\ University Ca' Foscari of Venice, \\ CSEF and CEPR
}

Discussion Paper No. 8071

March 2014

\author{
IZA \\ P.O. Box 7240 \\ 53072 Bonn \\ Germany
}

Phone: +49-228-3894-0

Fax: +49-228-3894-180

E-mail: iza@iza.org

Any opinions expressed here are those of the author(s) and not those of IZA. Research published in this series may include views on policy, but the institute itself takes no institutional policy positions. The IZA research network is committed to the IZA Guiding Principles of Research Integrity.

The Institute for the Study of Labor (IZA) in Bonn is a local and virtual international research center and a place of communication between science, politics and business. IZA is an independent nonprofit organization supported by Deutsche Post Foundation. The center is associated with the University of Bonn and offers a stimulating research environment through its international network, workshops and conferences, data service, project support, research visits and doctoral program. IZA engages in (i) original and internationally competitive research in all fields of labor economics, (ii) development of policy concepts, and (iii) dissemination of research results and concepts to the interested public.

IZA Discussion Papers often represent preliminary work and are circulated to encourage discussion. Citation of such a paper should account for its provisional character. A revised version may be available directly from the author. 
ABSTRACT

\section{Roadblocks on the Road to Grandma's House: Fertility Consequences of Delayed Retirement}

This paper investigates the role of childcare provided by grandparents for the fertility decisions of their offspring. We exploit a decade of pension reforms in Italy that mandated the grandparental generation to a working horizon longer than they would have had otherwise. We argue that the rise in retirement age meant a negative shock to the supply of informal childcare for the next generation. Our results show that one additional grandparent available in the early child-bearing years increases by about five percent the number of children. We show that the fertility effects of delayed retirement are limited to close-knits with a strong familistic structure. The result is not just the mechanical consequence of delayed exit from parental home, of more investment in education or of more attachment to the labour market. In light of the Italian lowest low fertility we conclude that pension reforms may have had unintended inter-generational effects. This conclusion is consistent with the sharp drop in total fertility documented by official statistics for the most conservative areas of the country.

JEL Classification: J08, J13, H42

Keywords: fertility, informal child care, pension reforms

Corresponding author:

Erich Battistin

School of Economics and Finance

Queen Mary, University of London

Mile End Road

London E1 4NS

United Kingdom

E-mail: e.battistin@qmul.ac.uk

\footnotetext{
* The manuscript benefited from comments by audiences at GSP (Brixen, Italy - February 2013), DONDENA Center for Research on Social Dynamics (Milan, April 2013), IRVAPP (Trento, May 2013), 27th Conference of the European Society for Population Economics (Aarhus, June 2013), 15th IZA/CEPR European Summer Symposium in Labour Economics (Buch, Ammersee, September 2013), as well as from discussions with Josh Angrist, Maria Castiglioni, Matteo Cervellati, Gianpiero Dalla Zuanna, Margherita Fort, Nicola Fuchs-Schündeln, Omar Paccagnella, Enrico Rettore, Serena Trucchi and Matthew Wakefield. Part of the project was developed while Erich Battistin was visiting the MIT Department of Economics. The financial support from the Italian Ministry of University and Research (Futuro in Ricerca 2008 - "The economic effects of demographic ageing") is gratefully acknowledged.
} 


\section{Introduction}

The demographic transition has caused profound revisions of social security systems in several developed countries. In many cases these reforms have meant a shift from a defined benefit to a defined contribution system, together with a gradual change of the minimum retirement age aimed at increasing labor market participation at the end of the life-cycle (see Milligan and Wise 2012). On the one hand, by acting on eligibility rules and the return on mandatory saving to retirement, pension reforms affect consumption, saving and labor supply decisions of the targeted individuals, ${ }^{1}$ On the other hand, to the extent that individuals are altruistically linked, the effect of reforms on one generation may spill over generations that are not directly affected. We argue that pension reforms, by lengthening the working horizon of individuals, induce a negative shock to the supply of informal childcare potentially available to the next generation. We therefore investigate the inter-generational effects of these reforms on the fertility decisions of the offspring generation. ${ }^{2}$

We expect these effects to be most pronounced in those countries where the usage of grandparental childcare is widespread and culturally well accepted. Moving from this idea, we take Italy as case study and consider a number of reforms of the social security system that took place during the 1990s and mandated individuals to a substantially longer working horizon. We link information for the generation affected by these reforms to life history data for the offspring generation. To this end, we employ newly released data from the Family and Social Subjects survey (October 2012), which is part of an integrated system of social surveys carried out by the Italian National Statistical Office on daily lives of individuals and families. This allows us to study differences in fertility and labor supply decisions across couples indexed by their parents' status with respect to reforms in the 1990s.

A common issue in this literature, to which our identification strategy offers a new solution, is the endogeneity of childcare utilization with respect to both fertility and labor supply of mothers. A wide range of government interventions may in principle affect the

\footnotetext{
${ }^{1}$ Recent work has considered the effects on consumption (Battistin et al. 2009), saving (Attanasio and Brugiavini 2003), wealth (Bottazzi et al. 2006), portfolio choice (Bottazzi et al. 2011) and labor supply (Liebman et al. 2009).

${ }^{2}$ While the literature on the intra-generational effect of reforms on saving and labor supply is quite extensive, to the best of our knowledge only one paper, Billari and Galasso (2010), looks at the effect on intra-generational fertility and exploit pension reforms as a source of exogenous variation to test two alternative theories: children as 'consumption' versus 'investment' good.
} 
demand for childcare, be it formal or informal. However, for policies that impact directly on maternal work (e.g. minimum wage, changes to tax credits and benefits, or maternity leave and pay flexible working rights) the validity of the exclusion restriction is not always uncontroversial. Also, policies altering the nature of childcare choices or costs usually target 'formal' channels (e.g. tax-free childcare vouchers provided by employers, or extended instruction time at school; see Schlosser 2006 and Mörk et al. 2009 for examples). We mark something of a departure, and instead consider exogenous shocks to the supply of 'informal' childcare across generations. By focusing on cohorts of parents whose fertility and education decisions were already taken in the 1990s, our key identifying assumption is that the fertility of the offspring generation is altered by changes to the social security system only through their effect on parents' labor supply.

The empirical relevance of our research question is grounded on the role of time devoted by grandparents to the care of grandchildren. Despite various examples of government investment to boost formal childcare policies, the number of households using informal childcare provided by grandparents remains high in many countries. Cardia and Ng (2003) report that in the US Health and Retirement Survey grandparents devote an average of 8 hours per week to the care of their grandchildren. García-Morán and Kuehn (2012) use the Survey of Ageing and Retirement in Europe to show that between 23 to 70 percent of grandparents take care of their grandchildren on a daily or a weekly basis. Bryson et al. (2011) report that about 16 percent of UK households have a child's grandparent offering childcare while parents work; they estimate that these are twice as many households as those using formal alternatives such as nurseries or school clubs. While the incidence of care provided by grandparents varies significantly between Northern, Central and Southern European countries, the time transfers across generations are quantitatively important in all countries compared to other in-kind or money transfers (see Albertini et al. 2007) $\mathrm{H}^{3}$

Italy is no exception to this general pattern, but presents peculiarities that are important for our research question. There are 11 million grandparents in the country, representing

\footnotetext{
${ }^{3}$ In light of these numbers, informal childcare and the support to informal carers - mainly represented by grandparents - is now high on the policy agenda of many European countries. For example, in 2010 the UK Department for Work and Pensions announced a consultation for allowing parents to transfer national insurance credits to the grandparents providing childcare. In Germany, the Federal Minister of Families Kristina Schröder has recently made a law proposal to grant grandparents the right to unpaid leave (up to 3 years) in order to take care of their grandchildren.
} 
about one third of the population aged above 35. This percentage is higher for Central and Southern regions, where it picks at above 40 percent and is mirrored by lower kindergarten coverage. According to our data, grandparents hang around regularly with grandchildren: 42 percent of them daily, and 39 percent at least once a week. Most importantly for the purpose of this paper, official figures from the National Statistical Office report that 86 percent of grandparents actively contribute to childcare, grandmothers being the most involved. $4^{4}$ Taken at face value, the above figures suggest that the role played by informal institutions in Italy marks a significant departure from other European countries. Besides, Italy is an interesting case of study as it presents substantial variability in familistic culture across regions, the role of extended families being more important in the South (Banfield 1958).

We exploit this institutional setting and, in contrast with the literature considering crosscountry variability, we employ within country variability to investigate how changes to the working horizon of one generation affect the organisation of the close-knit and the behaviour of its members, and how cultural factors interact with the shock. This is a potentially important channel, as we know that social norms predict a somewhat stereotyped behavior in an individual's life cycle. Living arrangements in a familistic society are different, and the practice to leave the parental home only for marriage is widespread 5 This in turn may affect fertility, as well as labor supply decisions: a familistic culture supports a more traditional role for the woman, and a pronounced division of labor between male and female members of the family (Giuliano 2007 and Alesina and Giuliano 2010). Arguably the existence of strong family ties is associated with more reliance on extended family members for the provision of goods and services, like childcare. In this setting, geographic proximity represents an important form of insurance, and reinforces cooperation bonds amongst family members. At the same time, it implies that access to the market and public services is, ceteris paribus, less of a need. According to official figures, the mother of 5.5 percent of married individuals in Italy lives in the same building; above 22 percent of mothers live in the same town, and

\footnotetext{
${ }^{4}$ The time granted by grandparents is not only related to occasional commitments of parents (25 percent), but also to their working hours (24 percent). Babysitting (12 percent), sickness of grandchildren (9 percent) and holidays (9 percent) are additional occasions of childcare provision.

${ }^{5}$ Accordingly, some 40 percent of individuals aged between 25 and 34 in Italy live with their parents. Becker et al. (2010) relate it to the lower job insecurity of parents compared to children. Manacorda and Moretti (2006) argue that it is due to the parents' taste for cohabitation. Giuliano (2007) relates the high rate of co-residence in Southern European countries to the sexual revolution of the 1970s that liberalized parental attitudes towards pre-marital sex, and emphasizes the role of cultural attitudes in determining living arrangements.
} 
11.9 percent within a mile; 76 percent of individuals meet regularly one of their parents on a weekly basis. As we shall show below, these numbers are higher in the most conservative regions of the South. One may think that parental proximity is peculiar to the anthropological family structure of the Italian society, but in fact this is not the case. For example, Compton and Pollak (2013) find that, in the US, the median distance from mothers is 20 and 25 miles for adult males and adult females, respectively, and conclude that the pattern of inter-generational proximity is gendered.

On the other hand, independently of culture, it is well known that child raising costs might have a sizeable impact on fertility and employment decisions of mothers. Billari and Tabellini (2010) report data on the share of young adults (aged 15-24) who declare to be financially dependent on their parents. They show that Italy ranks among the highest share countries (74 percent), together with Greece and Spain..$^{6}$ In this context we expect higher costs, ceteris paribus, for couples with few immediate family ties and who solely depend on the formal provision of services. Blau and Robins (1989) use a sample of labor-market and life-histories and show that higher childcare costs reduce the birth rate for non-employed women, increase the probability of leaving employment, and reduce that of entering the labor-force. Del Boca and Vuri (2007) focus on how the childcare institutions in Italy affect labor market decisions of mothers, and Dimova and Wolff (2011) focus on Europe and find a strong positive effect of grandchildcare on the labor force participation and the degree of labor market involvement of the young mother. García-Morán and Kuehn (2012) provide a quantitative model to investigate the effects of grandparent-provided care on fertility and labor supply decisions. Bick (2011) provides a life-cycle model incorporating both paid and un-paid care to children, showing that the lack of subsidized childcare is an obstacle to female labor market participation and depresses fertility. Compton and Pollak (2014) find that geographical proximity of grandparents in the US, and of mothers and mothers in law in particular, affects positively the labor supply of women with children 12 and under. They argue that the likely mechanism is childcare.

\footnotetext{
${ }^{6}$ These patterns also affect how wealth is transmitted across generations in Italy. Guiso and Jappelli (2002) show that inter-generational monetary transfers make households purchase considerably larger homes. Cannari and D'Alessio (2008) show that received transfers account for between 30 and 55 percent of the net wealth held by households. Jappelli et al. (2013) show that the fraction of households receiving real estate transfers rises from 30 percent in 1993 to just above 35 percent in 2006. Tomassini et al. (2003) study the importance of parents' financial help for housing tenure of their offspring, and show that inter-generational transfers are typically employed to purchase a house.
} 
The presentation of our findings is structured as follows. First, we show that the pension reforms implemented in Italy during the 1990s affected markedly the working horizon of individuals. As we will discuss further below, the cohorts considered comprise only individuals whose educational and fertility choices were taken at the time of reforms. This is an important point that we use to rule out the existence of multiple inter-generational channels. We document negative effects of the reforms on retirement probabilities of about 5 percent at age 50, which up to 1992 was the minimum retirement age set by law. In light of the steep transition rates from work to retirement in the 50 to 55 age range observed before 1992, we conclude that the reforms lengthened by about 5 years the working horizon of individuals. Manacorda and Moretti (2006) and Battistin et al. (2009) document similar effects on labor market participation rates using data from the Bank of Italy.

Second, we present results from reduced form regressions of fertility for households whose families of origin were differentially affected by the reforms. The thought experiment sets up the comparison of same-age females with observationally identical parents and parents in law but mandated to increasingly longer working horizons because of the reforms. We show that the number of parents eligible for pension benefits, which we use to proxy potential availability for informal childcare, has an important effect on fertility. One additional parent available in the early child-bearing years (during the 20s) increases by 5 percent the number of children in the household. We find that the fertility effects of pension reforms are more pronounced for family types oriented to a family-intensive social organization technology. As fertility in our data is measured in 2009 at the latest, we are not able to discuss whether the limited access to informal childcare results in a postponement of fertility decisions to the late child-bearing years (during the 30s) or in a permanent change. We however use official statistics to show that the marked differential in total fertility rates between the most and the least family-intensive areas of Italy started to close for generations of females whose parents were the most affected by the reforms. Consistently with our interpretation, the fertility gap between the two areas was fairly stable until that time.

In addition, we shed light on the possible channels at work behind these results. We start by investigating whether reliance on grandparental help reflects preferences or follows from financial constraints and/or lack of access to formal childcare. We show that the effects on fertility do not vary with household wealth once family ties are taken into account, and 
that this conclusion is robust to the indicator of wealth employed. Also, we reach the same conclusion once we investigate the role of publicly provided childcare. We therefore conclude that the effects of grandparental availability are driven by preferences and social norms, consistently with the idea that familistic societies attribute more value to members of the extended family. We also document gender differences in the role of grandparents. The effects of grandparental availability are solely driven by availability of maternal grandparents, with a more pronounced role of the grandmother.

Finally, we explore the importance of two other margins of adjustment: labor supply and education. Changes in fertility decisions and the reduction of informal childcare may have resulted in increased labor market participation, and/or more investment in education. We do not find any inter-generational effect on labor supply. In line with our findings, recent work on Sweden - a high fertility rate country - has shown a limited effect of childcare policies on labor supply of the women (see Lundin et al. 2008). Other evidence for lower fertility countries, including Italy, seems also in line with our results. Nicodemo and Waldmann (2009) show that in Mediterranean countries a very high percentage of women who do not work use non-parental childcare arrangements. We find a positive effect of number of grandparents available on the probability of obtaining a college degree, regardless of the extent of family ties. This suggests that the effect on fertility works over and above that on education.

The remainder of the paper is organized as follows. Section 2 describes pension arrangements in Italy, introduces the data and explains the sample selection criteria adopted in the empirical analysis. Following a brief graphical analysis in Section 3 . Section 4 first discusses the effects of pension reforms on labor supply of the parental generation, and then shows the fertility effects of delayed retirement. Section 5 discusses the mechanism behind our results and the role of alternative channels, and also provides falsification tests for the validity of our identifying restrictions. Conclusions and policy implications are deferred to Section 6 .

\section{Institutional background and data}

\section{Pension arrangements in Italy}

In the time window relevant to our analysis, pension benefits were conditional on eligibility obtained through old age or seniority criteria. In the former case benefits could be claimed 
after having reached a certain statutory age set by law. In the latter case eligibility depended on the number of years of contributions accrued, independently of age. Eligibility for pension benefits was obtained whatever of the two conditions was met first.

Until 1992 replacement rates were high, pension benefits were computed on the basis of the earnings-model and generous early retirement schemes were available. The ratio of pension benefits to GNP reached almost 16 percent in 1992, the highest value among industrialized countries. To respond to the growing unbalance, three reforms were rolled out between 1992 and 1997. The aim was to gradually tighten eligibility criteria by increasing the statutory retirement age and the minimum years of contributions, abolishing seniority criteria for individuals who entered the labor market after 1995, and indexing pension benefits to prices rather than wages $]^{7}$

The change to eligibility conditions was massive and is most simply understood by considering Figure 1, where reported is the minimum retirement age calculated from seniority and old age criteria (for a discussion of the institutional details underlying the computation see, for example, Bottazzi et al. 2006 and Battistin et al. 2009). The figure sets out the comparison of consecutive cohorts of individuals indexed by the year in which they reach age 50. A 13 year window is considered that spans the period relevant to our empirical exercise (1992-2004). A breakdown is considered by gender and sector of activity (public, private and self-employment), which represent the dimensions explicitly mentioned in the law. We also stratify by educational attainment (high school drop-outs, high school graduates and college graduates), which we use to compute years of contributions accrued since entrance in the labor market. To this end, although our data contain information on age at first job, age when highest qualification was attained, and employment histories for all interviewees, we adopt definitions that are unaffected by errors in self-reported measurements. In particular we assume continuous working careers from the year when the highest qualification was attained, and impose a common age of entrance in the labor market for all individuals sharing the same educational attainment (15, 19 and 24 for the three incremental categories

\footnotetext{
${ }^{7}$ The first of these reforms was presented in the second half of 1992 by the Government led by Giuliano Amato, and it is known as 'Amato' reform. The other two reforms were passed in 1995 and 1997, when Lamberto Dini and Romano Prodi, respectively, were in charge. These reforms are known as 'Dini' and 'Prodi' reforms. In 2001 the government led by Mario Monti abolished seniority pensions and introduced for early pension scheme, which is accessible by male (female) workers who contributed for at least 42 (41) years. It will follow from the sample selection criteria that all cohorts considered entered the labor market before 1995. This is why we maintain the distinction between seniority and old age criteria in Figure 1 .
} 
considered, these being ages when the qualification is typically attained according to the Italian education system).

The evidence suggests that for the cohorts considered eligibility for seniority pensions was, by and large, the binding requirement. For example, until 1992 males employed in the private sector qualified for old age pensions at age 60, and for seniority pensions at any age provided that they had accumulated at least 35 years of social security contributions. As a result, until 1992 male private employees with a continuous working career from age 15 could retire as early as age 50. Accordingly, high school drop-outs working in the private sector aged 50 in 1992 are eligible for seniority pensions, but fall 10 years behind eligibility for old age pensions (see the left hand side graph in the top panel of Figure 1). College graduate in the private sector entered the labor market 9 years later, and thus in 1992 cannot claim pension benefits (see the right hand side graph in the top panel). Notably, the minimum number of years of contributions for public workers was 20 up to 1992, making retirement not uncommon for individuals in their forties.

In the new regime the statutory retirement age was raised for private sector employees (e.g. from 60 to 65 for males), but not for public employees. Access to seniority pensions still requires at least 35 years of contributions, but provided that a minimum age condition is also met. This explains the gradual increase in years to eligibility that is observed as we move to the right of each panel. It emerges that relatively close cohorts of individuals faced, because of the regulatory interventions, sharp changes to their eligibility rules.

\section{Working sample}

We use data from the newly released wave of the Multiscopo Survey, conducted by the Italian National Statistical Office in 2009 and released in October 2012. In particular, we use the Famiglia Soggetti Sociali - Condizione Infanzia (Family and Social Subjects) section of the survey. This is the third wave of a large cross sectional survey conducted every six years which collects detailed retrospective information on employment occasions and fertility decisions for each member of the sampled household. The frame is designed to yield a sample of about 18,000 households representative of the Italian population.

Our setting considers three generations of individuals. We will label as grandparents those for whom we define the pension reforms status in the 1990s. Fertility will be measured 
for the offspring of this group. Also we will at times refer to children of the latter generation, which we will label as grandchildren. The offspring generation is used as pivotal group to define the working sample. By looking at official figures for the average age at first child, we selected married or co-habiting couples whose female member is aged between 23 and 37 during the reforms roll out (1992-2004). Individuals were interviewed in 2009, and detailed (current and retrospective) information was collected on significant events in the life of all household members. It follows that for both members in the couple we are able to reconstruct life cycle employment and fertility decisions until 2009. Other than event history data, the survey collects unique information on a broad spectrum of demographics describing the social background of the family. In particular, it provides detailed information on family structure, current and past close-knit networks and informal help and assistance received during critical events, life of the couple, relationship with the family of origin, help provided to children by family members and relatives, permanence of young adults in the family, careers of all family members and social mobility. Will refer to the 4,333 couples in this group as 'Main Sample', for which descriptive statistics are presented in the left hand side panel of Table 1 .

Most importantly for the purpose of this paper, for both members of the couple demographics were collected on the families of origin. These consist of education, year of birth and a coarse indicator of the main occupation of both the father and the mother of the interviewee. By using these variables and the rules described in Section 2, we imputed pension eligibility of all members in the family of origin. It follows that we are able to retrieve labor supply and fertility information at various ages of the female member of the Main Sample, and relate these to the pension eligibility status at that age of members of her family of origin as well as of those of her partner.

In the spirit of the two-sample instrumental variable idea (Angrist and Krueger, 1992), we used year of birth of members in the family of origin to construct an additional sample. This consists of individuals interviewed in 2009 and born in a time window that matches that of grandparents in the Main Sample. Summary statistics for the year of birth of grandparents as obtained from the Main Sample are in Table 1, while the full distribution is presented in Figure A.1 By considering these figures we selected males and females born between 1925 and 1955, regardless of the marital status declared in 2009. This yielded a sample with 6, 467 males and 7,399 females, which we will label as 'Sample of Grandparents' and use to 
investigate the direct effects of the pension reforms taking advantage of the event history modules of the questionnaire. Replicating the procedure followed above, for all individuals in this sample we imputed the pension eligibility status at various ages. We can therefore define the employment life cycle histories and retirement decisions for all individuals in the Sample of Grandparents, and relate these to the exogenous changes introduced by the reforms. Descriptive statistics are presented in the right hand side panel of Table 1.

\section{Descriptive statistics and graphical analysis}

\section{Pension eligibility and labor supply}

Our investigation of pension reforms begins by deriving descriptive evidence in Figure 2 that is suggestive of sizeable effects on labor market participation of individuals in the Sample of Grandparents. The graphical analysis presented is derived according to the following procedure. As in Figure 1, the horizontal axis runs over groups indexed by the year in which the individual reaches age 50. The top panel reports, for each cohort, the average minimum retirement age of individuals calculated from seniority criteria as explained above. The bottom panel reports cohort percentage of employed individuals at 53 and 55, as the available empirical evidence suggests a substantial transition to retirement in this age range before 1992 (see, for example, Battistin et al. 2009). To limit the number of figures, we present results only for male individuals.

The discontinuity in employment probabilities depicted in the bottom panel mirrors the discontinuity of pension eligibility in the top panel. As summary statistics, we computed regressions of minimum retirement age on a post-reform dummy and a second order polynomial in cohort, controlling for region fixed effects. Results suggest that the number of years to pension eligibility increased for males by about 5 years for males employed in the private sector, and to nearly 9 years if we consider public workers and self-employed.

We will use between cohort variation in pension arrangements as an exogenous shock to the labor supply of grandparents, and through this to the available time they could devote to the care of grandchildren. The thought experiment sets out the comparison of same age females with observationally identical parents and parents in law mandated to increasingly tighter requirements for pension eligibility. The source of variability employed is presented in Figure 3, which is computed from the Main Sample. The horizontal axis refers 
to the cohort of birth of the female member of the couple. Each point on the vertical axis reports the residualised total number of eligible grandparents in the household at different ages of the female member of the couple, residuals being taken with respect to age and education of grandparents. This quantity before taking residuals represents the total number of grandparents potentially available for childcare, and will be used in the regressions below. It is clear that females born in the 1970s lived their twenties and thirties in a setting with a substantially lower potential supply of childcare with respect to older peers born in the 1960s. The question is whether this change induced by the implementation of pension reforms reflects into differential fertility decisions.

\section{Family ties and the role of culture}

Using a number of variables on the relationship of individuals in the Main Sample with their families of origin, we derived an indicator for the strength of family ties. For both members of the couple we have information at time of interview on the place of residence of their parents, on the modality and frequency of contacts (visits or telephone calls) and on whether they meet regularly for lunch or dinner over Sundays or week ends. In addition, we have information for whether the couple at the time of marriage received financial help to buy the house, and on parental place of residence at that time. We extracted the first principal component from 6 variables spanned by this information, and standardised the index so that it increases with the extent of family ties. We attributed strong family ties to those couples with values of this index above its sample median. Figure A.2 plots the geographical distribution of the percentage of households with strong family ties, and delivers a picture consistent with evidence that others have already documented from different data (see, for example Alesina and Giuliano 2013). Summary statistics are presented in Table $\left.2\right|^{8}$

Implicit is the idea that pension reforms did not alter the extent of family ties, for example through effects on mobility of individuals that depend on the working horizon of

\footnotetext{
${ }^{8}$ Consistently with Alesina and Giuliano (2013), we show in Figure A.2 that family ties are negatively correlated with female labor force participation in 2009 (although the same conclusion holds up when different years are considered). Moving causality to the background, the figure is suggestive of persistent effects of cultural norms across economic conditions and of a more traditional role for the woman in environments with strong family ties. Also presented in Figure A.3 is the distribution across areas of per-capita number of seats at kindergarten in 2009, which we used to proxy the supply of public (formal) childcare. This information, collected by the Italian National Statistical Office, is available only from 2003 and is therefore not used in equation (3). The association between ties and childcare availability is worth of notice.
} 
their parents. This is an assumption for which we cannot provide direct evidence using one wave of data, as information on proximity of grandparents is collected only at time of interview. We circumvent the problem by pooling the three existing waves of Multiscopo Survey. Although the different structure of some modules across survey waves does not allow us to pool data for estimating our main equations of interest, information on family ties is consistently collected over time. We therefore use this feature to contrast indicators of proximity between grandparents and adult offspring as measured in three occasions (1998, 2003 and 2009). We select cohorts of grandparents by taking a five-point window centered at those who were the first to be affected by reforms (i.e. those born in 1946 and aged 50 in 1996, as seen in Figure 2). Straightforward calculations show that by pooling cohorts born between 1940 and 1945 (pre-reform) we can measure proximity at all ages between 53 and 68.9 Similarly by pooling cohorts born between 1946 and 1950 (post-reform) proximity can be computed at all ages between 48 and 63 .

We set out the comparison between pre- and post-reform cohorts with respect to various indicators of distance. We kept all individuals born between 1940 and 1950, and computed (a) percentage living in the same municipality of their offspring; (b) percentage having lunch or dinner with offspring regularly on Sundays; (c) percentage meeting offspring at least once a week; (d) percentage calling offspring at least once a week. For each indicator of proximity, $t_{c a}$, we estimate:

$$
t_{c a}=\mu(a, c)+\beta \mathbb{1}(c \geq 1946)+\eta_{c a}
$$

where $c$ and $a$ are, respectively, cohort and age, $\mu(a, c)$ is the parametrization adopted for age and cohort effects (quadratic polynomials), $\mathbb{1}(c \geq 1946)$ is an indicator for post reform cohorts and standard errors are clustered by cohort. Estimation is carried out by limiting the analysis to the age range $53-63$ to ensure full support. Results are presented in Table 3. and show relatively precise zeros for the post reform coefficient associated to all indicators of family ties. The graphical analysis in Figure A.4 also confirms substantially parallel age profiles for family ties for pre and post reform cohorts.

As an alternative robustness check, we experienced with alternative definitions of family

\footnotetext{
${ }^{9}$ Proximity is reported in 1998, 2003 and 2009. Thus for any cohort of parents $c$ we can compute a measure of distance from adult offspring when individuals in the cohort are aged $a, a+5$ and $a+11$, with $a=1998-c$.
} 
ties to limit the spurious effects of differential mobility between pre- and post-reform cohorts. We defined ties independently of proximity relying only on the frequency of telephone contacts. It turns out that this alternative definition yields qualitatively the same results presented in Table 5 below. These results are documented in Table A.1.

\section{Empirical framework}

\section{Effects of pension reforms on parental labor supply}

Moving from the non-parametric analysis above, we now investigate the statistical relevance of the effects documented by framing the problem in a regression setting. We start from information in the Sample of Grandparents. Labor force participation of individual $i$ at age $a, y_{i a}$, is modelled as a polynomial function of cohort of birth, $c_{i}$, the indicator for pension eligibility at age $a, z_{i a}$, and a set of demographics and area-level characteristics that are agespecific, $\mathbf{w}_{i a}$. The latter set comprises variables that vary over time and, through this, with age of individuals. Conditional on age and demographics, identification of the coefficient on $z_{i a}$ is obtained using variability across cohorts. In light of the sample selection criteria adopted, we restrict the analysis to the range $a=50, \ldots, 57$ for high school dropouts and $a=50, \ldots, 60$ for high school graduates as, away from this range, little variability in $z_{i a}$ is observed in our data. We report results from the following specification estimated by gender:

$$
y_{i a}=\rho_{0}(a)+\sum_{a=50}^{60} \alpha_{a} d_{i a} z_{i a}+\rho_{1} c_{i}+\rho_{2} c_{i}^{2}+\rho_{3} \mathbf{w}_{i a}+\varepsilon_{i a},
$$

where $d_{i a}$ is the indicator for individual $i$ having age $a$. In practice age effects are modelled through a quadratic polynomial in age $\rho_{0}(a)$, and we impose that the coefficients on cohort and $\mathbf{w}_{i a}$ are constant with age as results proved robust to this choice. In our specification, $\mathbf{w}_{i a}$ consists of a full set of dummies for region of residence and educational attainment. Throughout the analysis standard errors are clustered by cohort, education and sector of activity, which together define the level of variability of the variable $z_{i a}$.

Results from specification (2) are reported in Table 4, separately for males and females. The breakdown by educational attainment is also considered, as the age range relevant to retirement decisions varies importantly along this dimension. The focus here is on the effects of introducing more stringent eligibility requirements on labor supply. Because of this, equation (2) is estimated excluding homemakers. We define this group by selecting 
females who have been permanently out of the labor force over the life cycle. This group represents almost 40 percent of females in the Sample of Grandparents.

Columns (1) and (4) report results by gender for the full sample. Eligibility for pension benefits has a negative effect on labor force participation at all ages, and this effect increases as the individual ages. For example, eligibility acquired for males by age 55 makes retirement at that age more likely by about 8 percent. As pension reforms gradually increased old age requirements to 65 and 60 for males and females, respectively, it is reassuring to notice that the effects in column (4) shrink as the individual approaches age 60. Columns (2) and (3) make clear that age-specific effects for males are non-parametrically identified using information for individuals with different educational qualifications. Columns (5) and (6) convey the same information in the sample of females.

Overall results point to important effects of pension reforms on labor force participation, and are in line with previous evidence documented from different data Manacorda and Moretti 2006 and Battistin et al. 2009). In particular, the regression discontinuity strategy in the latter paper shows that for a large portion of individuals the decision to exit the labor market was taken upon obtaining eligibility.

\section{Fertility effects of delayed retirement}

Estimation is carried out using data from the Main Sample. Fertility of female $j$ at age $a$ is measured by a dummy for being mother at that age, $f_{j a}$, over the range $a=23, \ldots, 37$. The following specification is considered:

$$
f_{j a}=\delta_{0}(a)+\sum_{a=23}^{37} \gamma_{a} d_{j a} \bar{z}_{j a}+\delta_{1} c_{j}+\delta_{2} c_{j}^{2}+\delta_{3} \mathbf{x}_{j a}+u_{j a}
$$

where $c_{j}$ is cohort of birth of the female, $\delta_{0}(a)$ is a quadratic polynomial in age and $\mathbf{x}_{j a}$ are age-specific demographics. The variable $\bar{z}_{j a}$ is computed as number of members in the family of origin (parents and parents in law) who are eligible for pension benefits when the female member of the couple is aged $a$. Age profiles are modeled non-parametrically through interactions defined by the dummies $d_{j a}$ 's for equally spaced age bands spanning the $23-37$ interval. Identification of these coefficients rests upon the variability in Figure 3.

Due to coarse information on the sector of activity for members in the family of origin, we impute pension eligibility from cells defined by gender and education using rules for private 
sector workers (i.e. using the top row of figures from both panels in Figure 1). We do so also for homemakers in the families of origin, which can be identified with some caveats that we discuss in Section 5. The inclusion of homemakers in the grandparental generation does not affect the validity of our identification strategy. This group consists of 'never' takers with respect to pension reforms, and thus does not convey useful information for estimating the parameter we are after.

Controls in $\mathbf{x}_{j a}$ can be grouped into three categories. First, we use variables that are directly related to the couple; these are education of head and spouse, age of the male member, region of residence and regional female employment rate. Second, we use characteristics that are related to composition of the family of origin and which are member specific: dummies for being still alive, age and education. The latter variable is meant to net off lifetime resources in the family, which most likely are transmitted across generations; age effects are instead used to capture differential propensity or availability of older members to provide childcare. Finally, we include number of siblings of couple's members to model the potential competition for grandparental time between young relatives, and a dummy for being the first born male in the family of origin to control for preferences frequently encountered in familistic environments.

The main results are in columns (1)-(3) of Table 5, where presented is the effect of number of grandparents available on the probability of being mother. Column (1) indicates that the effect is positive and statistically significant after age 29, which for the years after the reform according to official figures is close to the average age at first child in Italy. One additional grandparent available at that age increases the likelihood of being mother by 3 percent. In columns (2) and (3) we investigate the interplay between cultural factors and changes to the close-knit by stratifying for family ties. We find that column (1) masks important heterogeneity along this dimension, as the effects of grandparental availability come from the most familistic environments. Columns (4)-(6) and (7)-(9) focus on the probability of having more than one child and on number of children, respectively. A drop in the supply of available grandparents affects total fertility during child-bearing years.

There is a vast empirical literature on the role of culture and family ties for fertility and female labor supply decisions. The general conclusion is that social norms in southern European countries affect living arrangements, and that are strong predictors of a more tra- 
ditional role of the woman in the society. Youths move out of parental home for marriage, do not cohabit, and the male breadwinner culture affects both female labor market participation (Alesina and Giuliano 2010) and fertility decisions (Fernández and Fogli, 2009). The results in column (10) of Table 5 show a negative association between the probability of living with parents and their eligibility for pension benefits. The finding is consistent with the interpretation offered by Manacorda and Moretti (2006) on the role of parents in the nest-leaving process. Parents' labor income allows them to offer their children higher consumption in exchange for their presence at home. Manacorda and Moretti (2006) use the same pension reforms that we consider here to instrument for disposable income at the household. Column (10) offers a reduced form interpretation of their results, implying that young individuals whose parents are affected by reforms delay exit from parental home.

In columns (11) and (12) we focus on households with weak and strong family ties. Results are driven by the weak family ties, suggesting that the effect on fertility operates over and above the effect on living arrangements. Should the effect on fertility follow mechanically from an effect on living arrangements, the latter effect would be higher with strong family ties. There are additional reasons to believe that the readiness for leaving the family if the 'bribe' is not adequate, as suggested by Manacorda and Moretti (2006), is not the most plausible channel at work given the institutional setting in Italy. Pension reforms have meant not only the postponement of retirement but also the reduction of pension benefits. As shown in Bottazzi et al. (2006), the effect on pension wealth is negative and the offset between private and pension wealth is below one, which implies a negative effect on overall wealth. Therefore, it is hard to describe pension reforms as a positive shock to wealth. In addition, even if only what matters is current disposable income, liquidity problems are unlikely to play a role. As discussed by Battistin et al. (2009), employees receive a large bonus payment upon retirement (technically: a severance pay), which implies that one would expect parents who retire being less cash constrained than those who do not retire.

\section{Additional evidence from official statistics}

To put our results in context, Figure 4 plots the number of children at age 32 against year of birth of the mother using published data from 1970 to 2012 as obtained from the official publications by the Italian National Statistical Office. The focus on the years of data 1970- 
2012 ensures the computation of fertility at age 32 for all cohorts of the Main Sample without resorting to approximations or projections. The vertical line refers to the cohort of females born in 1963, and aged 32 in 1995. Cohorts at the right hand side of this line spent an increasingly longer span of their reproductive cycle after the roll out pension reforms. For example, the cohort of those born in 1970 were 25 at the reform roll out, and fertility in Figure 4 reflects the cumulated effect of 7 years of exposure. Similarly, the 1975 cohort cumulates the effects from age 20 .

The continuous line in Figure 4 reports the average number of children by age 32 computed using residents in Southern Italy. Building upon the sharp geographical divide depicted in Figure A.2, we take the figures for the South as proxy for the fertility rate among strong family ties households. Similarly we use Northern regions to proxy the fertility rate among weak family ties households. The dashed line in the figure reports the difference between the continuous line and its counterpart constructed using only regions in the North and is termed the South-North differential.10

As documented by various studies in the literature (see, Caltabiano et al.|2009), fertility in the most familistic areas of the country has considerably declined for the youngest cohorts. The difference between cohorts born in the 1960s and in the $1970 \mathrm{~s}$ is about 0.5 children, out of nearly 1.8 children for those born in the later 1950s. Interestingly, the South-North divide was substantially stable until the 1963 cohort, with females in the South having on average 0.5 more children than those in the North. Fertility in Northern regions also steadily decreased for these cohorts, although it shows a turning point for the most recent cohorts born during the 1970s. These are facts that are all well documented in demography. The dashed line in Figure 4 shows that, despite the common trend across areas of the country, the drop in fertility was differentially more pronounced in the most familistic regions.

This pattern is consistent with results presented in the third panel of Table 5, which imply that pension reforms should have affected mostly environments characterized by strong ties. Taking Table 5 at face value the dashed line in Figure 4 can be given a difference in differences or a synthetic cohort interpretation (see Abadie et al. 2010), with Northern

\footnotetext{
${ }^{10}$ Either definition was obtained using official administrative borders. The Northern territory consists of the following regions: Piemonte, Valle d'Aosta, Liguria, Lombardia, Veneto, Trentino Alto Adige, Friuli Venezia Giulia and Emilia Romagna. The Southern territory consists of Campania, Abruzzo, Molise, Puglia, Basilicata, Calabria, Sicilia and Sardegna.
} 
regions representing the counterfactual fertility for the South. Column (9) of Table 5 points at an estimated effect of about 0.08 children per additional grandparent available. This figure should be compared to an average of 1.55 children by the age 32 (i.e. 5 percent) for the cohort of females marginally unaffected by the reform at that age (i.e. 1963) living in the South. The stability of the difference before the 1963 cohort is also suggestive of important changes after the implementation of pension reforms, and this is consistent with our interpretation.

\section{$5 \quad$ Alternative channels at work and placebo tests Preference for grandparental childcare versus resources}

The results presented in Table 5 are silent about the channels driving the effect of grandparental eligibility on fertility of their offspring. On the one hand the evidence documented is consistent with strong preference for grandparental childcare. At the same time, the decision to rely on grandparents may be driven by the lack of affordable formal childcare opportunities.

To evaluate the importance of households resources for fertility decisions, we interact two proxies of wealth with $\bar{z}_{j a}$. The first proxy is based on educational attainment of family members, the second on house size. Results are presented in Table 6, columns (1)-(3) for the former and columns (4)-(6) for the latter proxy. In either case we conclude that the effects documented in Table 5 remain also in the absence of financial constraints. Using the education proxy, 'high wealth' households are defined by considering the highest educational attainment of the head and the spouse. To ensure some balance between groups we set the cut-off to high school graduates, although results are robust with respect to the definition adopted. The house size indicator first computes per-adult number of rooms in the house, and then classifies households over and below the area average to adjust for housing market prices. The effects of family ties dominate the effects of financial constraints, thus unveiling a latent taste for grandparental childcare in child-bearing decisions. The fertility decisions of close-knits are substantially unaffected by resources: effects estimated for 'low wealth' and 'high wealth' couples are similar and, if anything, larger in the latter group when education is considered. The house size proxy also does not yield any appreciable difference in the effect of pension eligibility between high and low income families. 
We also take a broader view of resources and classify as 'high wealth' those households living in areas with kindergarten coverage above the national median. We therefore exploit variability arising from close-knits with weak and strong ties living in socio-economic environments offering good coverage of public childcare. Figures released by the National Statistical Office indicate a strong geographical gradient in the per-capita number of kindergarten seats. Interestingly enough, this pattern is the mirror image of the geographic distribution of family ties in the country. Not only the South is distinguished by persistently higher unemployment and lower per-capita income, but it also presents a substantially lower number of public structures than Northern and Central regions (see Figure A.3 in Section A. For example the percentage of local authorities offering (free or almost fully subsidised) formal childcare varies between $24.3 \%$ in the South and $82.6 \%$ in the North-East. Columns (7)-(9) in Table 5 suggest that improved access to public childcare attenuates the effect of grandparental availability in the presence of weak ties. On the contrary, it leaves unchanged the effect with strong ties. The results replicate the same patterns documented in Table 5, and are consistent with the view that social norms shape preferences, and that familistic societies attribute more value to childcare provided within the extended family. ${ }^{11}$

\section{Grandmothers versus grandfathers}

As in a familistic society the division of labor (and the specialization) between men and women is more pronounced, the question then arises of whether the role of grandmothers is somewhat special compared to that of grandfathers. If this is the case, the preference for grandmothers may conceal important non-linearities in the effects documented in Table 5.

The issue is investigated in Table 7, where we focus only on couples where maternal and paternal grandparents are alive in order to keep the sample composition constant across all columns. Here $\bar{z}_{j a}$ is defined, in turn, as number of grandfathers and grandmothers available, number of maternal and paternal grandparents available, and as whether the maternal grandmother and grandfather are available. The first three columns of Table 7 consider availability of female members (top panel) and male members (bottom panel). The results point to important gender differences that are consistent with a more traditional role of the woman for the provision of chilcare. This interpretation is reinforced once we consider

\footnotetext{
${ }^{11}$ For a survey on the interaction between social norms on preferences, see Postlewaite (2011).
} 
the difference between column (2) and column (3), as gender differeces are almost entirely driven by the presence of strong family ties.

The available evidence documents variation of the quantity (and quality) of grandparental childcare between paternal and maternal kin (see Danielsbacka et al. 2011 and references therein). Accordingly, we investigate whether fertility decisions depend on the availability of maternal or of paternal grandparents. Therefore, in columns (4)-(6) of Table $7 \bar{z}_{j a}$ is the number of maternal (top panel) and of paternal grandparents (bottom panel). The results suggest that the baseline effect is mostly driven by the availability of maternal grandparents. The probability of being mother in the presence of strong ties increases by 0.100 (0.014) for each extra maternal (paternal) grandparent available at the age of 29-31.

Together with the results in the first three columns of the table, the evidence suggests that the effects on fertility are mainly driven by the availability of maternal grandmothers. This is directly assessed in columns (7)-(9) of Table 7, where we investigate whether, among maternal grandparents, the availability of grandmothers is quantitatively more important than that of grandfathers. This done in the right panel of Table 7 where $\bar{z}_{j a}$ is a dummy for whether the maternal grandmother (top) or the maternal grandfather (bottom) is eligible for pension. The results point to a larger effect of maternal grandmothers as opposed to maternal grandfathers. Among strong family ties households, the probability of being mother at the age of 29-31 increases by 0.142 if the maternal grandmother is eligible for pension, and by 0.062 if the maternal grandfather is eligible. The evidence from American data in Compton and Pollak (2013) also suggests that the relationship between transfers and proximity differs by gender, with married couples living somewhat closer to the mother of the female member.

\section{Fertility decisions with inactive grandmothers}

To the extent that grandmothers are homemakers, changes in pension legislation should not affect their availability as providers of childcare. We can use this idea to define a placebo test for the validity of our approach. We therefore estimate equation (3) on subsamples of couples depending on the number of homemakers in their families of origin. Results are presented in Table 8. The first panel is obtained by selecting couples in the Main Sample in which either the maternal or the paternal grandmother is a homemaker. The central panel is instead derived considering couples in which both the maternal and the paternal grandmother are 
homemakers. ${ }^{12}$ Despite the admittedly lower precision that results from these sample cuts, it is worth noting that grandparental availability becomes increasingly less important as the number of homemakers increases. This effect virtually disappears in the central panel of the table, consistently with the idea of the prominent role of grandmothers.

The last panel of Table 8 provides an additional check for the validity of our approach. To the extent that mothers are the primary childcare givers, one can expect a weaker effect of the availability of grandparents if the female member of the couple is inactive. We therefore estimate (3) on the subsample of couples in which the female member is a homemaker. The results presented in columns (7)-(9) of Table 8 suggest a vanishing role of grandparents when mothers are homemakers.

\section{Other margins}

Table 8 implies that the baseline results in Table 5 are mainly driven by working mothers, and raises the question of whether the labor supply of the female member of the couple also responds to changes in pension eligibility rules of grandparents. The issue is explored in Table 9, where results from equation (3) are presented using employment of the women as outcome. Columns (1)-(3) do not show any effect, indicating that labor supply is not the main margin of adjustment to the negative shock to informal childcare. The argument, however, neglects another potentially relevant margin of adjustment, education. Women whose parents eligibility status is switched by the reform could for example postpone fertility decisions and invest more in education. Therefore, columns (4)-(6) relate the attainment of a college degree to $\bar{z}_{j a}$ controlling for the same set of variables used as controls in Table 5 . The results indicate that one more grandparent available increases the probability of graduating from the college by between 1.1 and 2.2 percent. In the light of the main results, shown in Table 5, the across-the-board positive association between the level of education and pension eligibility of grandparents indicate that fertility is more compatible with investment in human capital in households where the support from grandparents is arguably stronger.

\footnotetext{
${ }^{12}$ Our definition is based on survey information about the working status of parents when the respondent was aged 14. Inactive mothers at that age are defined as homemakers. Of course inactivity at that age may not necessarily imply inactivity during child-bearing years of the female respondent. Back of the envelope calculations presented in Figure A.5 shed light on the extent of misclassification that we could possibly face by assuming that inactivity of mothers in the early years of a respondent's life implies permanent inactivity. We estimate the incidence of misclassification at 20 percent.
} 


\section{Conclusions}

Among the many ways in which generations are altruistically linked, the transfer of time for childcare plays an important role. Grandparents are widely recognized as primary providers of childcare across the social ladder and in various institutional settings, both in Europe and in the US. The effect of the availability of childcare on fertility decisions has been studied, but much less is known on the effect of grandparental childcare on the fertility decisions of the offspring generation. A recurrent issue is the possible simultaneity between grandparents' labor supply decisions and those of their offspring.

The demographic transition has raised life-expectancy and therefore has increased the time grandparents can spend with their grandchildren. However, the concurrent pension reforms, by raising the retirement age, have had the countervailing effect on the time grandparents can devote to the care of grandchildren. Interestingly, changes in pension legislation can provide the source of exogenous variation to study the effect of availability of grandparents' childcare on the fertility decisions of their offspring.

To assess the effect of grandparental childcare on fertility, we focus on Italy. Italy is an interesting case study for three reasons. First, Italy scores a low fertility rate in comparison with countries at the same stage of the economic development and records the postponement of fertility decisions of women born after the Sixties. Second, Italy underwent in the last decades a series of pension reforms, which provide the exogenous variation needed for the analysis. Third, Italy is a country where the family plays an important role, but where the strength of family ties considerably varies in society.

Exploiting data on the grandparents and parents generation, we find that the reduced availability of grandparents has a negative effect of fertility and this is much so in families where the family ties are stronger. The adverse effect on fertility can either be driven by preferences or by the lack of alternative childcare opportunities or by both. To shed light on the issue, we also explore the role of institutionalized childcare. To the extent that the effect is driven by parents' strong preferences towards grandparents' care, the availability of kindergarten should not attenuate the effect of availability of grandparents' care on fertility. Our results indicate that the availability of institutionalized childcare somewhat attenuate the effect on fertility, at a rate that is larger among the couple where family ties are weak. We interpret these results as evidence that the effect on fertility is mostly driven by preferences, 
but we cannot rule out a role for the availability of institutionalized childcare.

Overall, our evidence suggests that pension reforms have important side-effects on the transfers of time between the old and the young generations. While being unintended, the consequences of raising the retirement age of a generation affect the fertility decision of the offspring and have long lasting impact on the society as a whole. 


\section{References}

Abadie, Alberto, Alexis Diamond, and Jens Hainmueller, 2010, Synthetic Control Methods for Comparative Case Studies: Estimating the Effect of California's Tobacco Control Program, Journal of the American Statistical Association, 105(490), 493-505.

Albertini, Marco, Martin Kohli, and Claudia Vogel, 2007, Intergenerational transfers of time and money in European families: common patterns - different regimes?, Journal of European Social Policy, 17(4), 319-334.

Alesina, Alberto and Paola Giuliano, 2010, The power of the family, Journal of Economic Growth, 15(2), 93-125.

—, 2013, Family Ties, NBER Working Paper 18966, National Bureau of Economic Research, Inc.

Angrist, Joshua D. and Alan B. Krueger, 1992, The Effect of Age at School Entry on Educational Attainment: An Application of Instrumental Variables with Moments from Two Samples, Journal of the American Statistical Association, 87(418), 328-336.

Attanasio, Orazio P. and Agar Brugiavini, 2003, Social Security And Households' Saving, The Quarterly Journal of Economics, 118(3), 1075-1119.

Banfield, Edward C., 1958, The Moral Basis of a Backward Society, Free Press.

Battistin, Erich, Agar Brugiavini, Enrico Rettore, and Guglielmo Weber, 2009, The Retirement Consumption Puzzle: Evidence from a Regression Discontinuity Approach, American Economic Review, 99(5), 2209-26.

Becker, Sascha, Samuel Bentolila, Ana Fernandes, and Andrea Ichino, 2010, Youth emancipation and perceived job insecurity of parents and children, Journal of Population Economics, 23(3), 1047-1071.

Bick, Alexander, 2011, The Quantitative Role of Child Care for Female Labor Force Participation and Fertility, goethe University Frankfurt, mimeo. 
Billari, Francesco C. and Vincenzo Galasso, 2010, What Explains fertility? Evidence from Italian pension reforms, Working Papers 369, IGIER (Innocenzo Gasparini Institute for Economic Research), Bocconi University.

Billari, Francesco C. and Guido Tabellini, 2010, Italians Are Late: Does It Matter?, in Demography and the Economy, NBER Chapters, 371-412, National Bureau of Economic Research, Inc.

Blau, David and Philip Robins, 1989, Fertility, Employment, and Child-Care Costs, Demography, 26(2), 287-299.

Bottazzi, Renata, Tullio Jappelli, and Mario Padula, 2006, Retirement expectations, pension reforms, and their impact on private wealth accumulation, Journal of Public Economics, 90(12), 2187-2212.

— , 2011, The portfolio effect of pension reforms: evidence from Italy, Journal of Pension Economics and Finance, 10(01), 75-97.

Bryson, Caroline, Mike Brewer, Luke Sibieta, and Sarah Butt, 2011, The role of informal childcare: A synthesis and critical review of the evidence, Report, Bryson Purdon Social Research, Institute for Social and Economic Research, Institute for Fiscal Studies and NatCen Social Research.

Caltabiano, Marcantonio, Maria Castiglioni, and Alessandro Rosina, 2009, Lowest-low fertility: Signs of a recovery in Italy ?, Demographic Research, 21, 681-718.

Cannari, Luigi and Giovanni D'Alessio, 2008, Intergenerational Transfers in Italy, Technical Report 9, Bank of Italy, research paper.

Cardia, Emanuela and Serena Ng, 2003, Intergenerational Time Transfers and Childcare, Review of Economic Dynamics, 6(2), 431-454.

Compton, Janice and Robert A. Pollak, 2013, Proximity and Coresidence of Adult Children and their Parents: Description and Correlates, IZA Discussion Paper 7431, Institute for the Study of Labor (IZA). 
—, 2014, Family proximity, childcare, and women's labor force attachment, Journal of Urban Economics, 79, 72-90.

Danielsbacka, Mirkka, Antti O. Tanskanen, Markus Jokela, and Anna Rotkirch, 2011, Grandparental Child Care in Europe: Evidence for Preferential Investment inMore Certain Kin, Evolutionary Psychology, 9(1), 3-24.

Del Boca, Daniela and Daniela Vuri, 2007, The mismatch between employment and child care in Italy: the impact of rationing, Journal of Population Economics, 20(4), 805-832.

Dimova, Ralitza and François-Charles Wolff, 2011, Do downward private transfers enhance maternal labor supply? Evidence from around Europe, Journal of Population Economics, 24(3), 911-933.

Fernández, Raquel and Alessandra Fogli, 2009, Culture: An Empirical Investigation of Beliefs, Work, and Fertility, American Economic Journal: Macroeconomics., 1(1), 146-77.

García-Morán, Eva and Zoe Kuehn, 2012, With strings attached: Grandparent-provided child care, fertility, and female labor market outcomes, MPRA Paper 37001, University Library of Munich, Germany.

Giuliano, Paola, 2007, Living Arrangements in Western Europe: Does Cultural Origin Matter?, Journal of the European Economic Association, 5(5), 927-952.

Guiso, Luigi and Tullio Jappelli, 2002, Private Transfers, Borrowing Constraints and the Timing of Homeownership, Journal of Money, Credit and Banking, 34(2), 315-39.

Jappelli, Tullio, Mario Padula, and Giovanni Pica, 2013, Do Transfer Taxes Reduce Intergenerational Transfers?, Journal of the European Economic Association, 12(1), 248-275.

Liebman, Jeffrey B., Erzo F.P. Luttmer, and David G. Seif, 2009, Labor supply responses to marginal Social Security benefits: Evidence from discontinuities, Journal of Public Economics, 93(11-12), 1208-1223.

Lundin, Daniela, Eva Mörk, and Björn Öckert, 2008, How far can reduced childcare prices push female labour supply?, Labour Economics, 15(4), 647-659. 
Manacorda, Marco and Enrico Moretti, 2006, Why do Most Italian Youths Live with Their Parents? Intergenerational Transfers and Household Structure, Journal of the European Economic Association, 4(4), 800-829.

Milligan, Kevin and David A. Wise, 2012, Introduction and Summary, in David A. Wise, ed., Social Security Programs and Retirement around the World: Historical Trends in Mortality and Health, Employment, and Disability Insurance Participation and Reforms, National Bureau of Economic Research.

Mörk, Eva, Anna Sjögren, and Helena Svaleryd, 2009, Childcare Costs and the Demand for Children: Evidence from a Nationwide Reform, Working Paper Series 782, Research Institute of Industrial Economics.

Nicodemo, Catia and Robert Waldmann, 2009, Child-Care and Participation in the Labor Market for Married Women in Mediterranean Countries, IZA Discussion Papers 3983, Institute for the Study of Labor (IZA).

Postlewaite, Andrew, 2011, Social Norms and Preferences, in Jess Benhabib, Alberto Bisin, and Mathew Jackson, eds., Handbook for Social Economics, 31-67, Elsevier.

Schlosser, Analia, 2006, Public preschool and the labor supply of Arab mothers: Evidence from a natural experiment, mimeo, Hebrew University, Jerusalem.

Tomassini, Cecilia, Douglas A. Wolf, and Alessandro Rosina, 2003, Parental Housing Assistance and Parent-Child Proximity in Italy, Journal of Marriage and Family, 65(3), $700-715$. 
Table 1: Descriptive statistics for the working samples.

\begin{tabular}{|c|c|c|c|c|}
\hline & \multicolumn{2}{|c|}{ Main Sample } & \multicolumn{2}{|c|}{ Sample of Grandparents } \\
\hline & Males & Females & Males & Females \\
\hline \multicolumn{5}{|l|}{ Interviewee } \\
\hline Year of birth & 1965 & 1968 & 1942 & 1941 \\
\hline High school dropout & 0.44 & 0.38 & 0.69 & 0.77 \\
\hline High school graduate & 0.43 & 0.44 & 0.22 & 0.16 \\
\hline College graduate & 0.13 & 0.17 & 0.09 & 0.06 \\
\hline Private sector employee & 0.46 & 0.29 & 0.47 & 0.52 \\
\hline Public sector employee & 0.19 & 0.16 & 0.26 & 0.26 \\
\hline Self-employed & 0.27 & 0.12 & 0.27 & 0.22 \\
\hline Living in Northern regions & \multicolumn{2}{|c|}{0.43} & 0.43 & 0.43 \\
\hline Living in Central regions & \multicolumn{2}{|c|}{0.18} & 0.18 & 0.18 \\
\hline Living in Southern regions & \multicolumn{2}{|c|}{0.39} & 0.39 & 0.39 \\
\hline \multicolumn{5}{|l|}{ Family of origin } \\
\hline Average year of birth & \multicolumn{2}{|c|}{1939} & & \\
\hline Number parents alive & \multicolumn{2}{|c|}{3.38} & & \\
\hline High school dropout & \multicolumn{2}{|c|}{0.81} & & \\
\hline High school graduate & \multirow{2}{*}{\multicolumn{2}{|c|}{$\begin{array}{l}0.13 \\
0.03\end{array}$}} & & \\
\hline College graduate & & & & \\
\hline Number of individuals & \multicolumn{2}{|c|}{4,333} & 6,467 & 7,399 \\
\hline Number of observations & \multicolumn{2}{|c|}{35,019} & 54,067 & 60,453 \\
\hline
\end{tabular}

Note. The Main Sample consists of married or co-habiting couples whose female member is aged between 23 and 37 in the period 1992-2004. The Sample of Grandparents consists of males and females born in the period 1925-1955. Reported is the number of individuals, and the total number of observations that results from individual panel data at different ages. For details about selection criteria adopted see Section 2

Table 2: Summary statistics by family ties

\begin{tabular}{lccc}
\hline & \multicolumn{3}{c}{ Family ties } \\
\cline { 2 - 4 } & All & Weak & Strong \\
\cline { 2 - 4 } & & & \\
Living in the same municipality of parents & 0.75 & 0.54 & 0.96 \\
Having Sunday lunch with family & 0.28 & 0.15 & 0.39 \\
Meeting offspring regularly & 0.80 & 0.64 & 0.96 \\
Calling offspring regularly & 0.85 & 0.84 & 0.86 \\
& & & \\
Years to first child after leaving parental home & & & \\
within 1 year & 0.37 & 0.32 & 0.41 \\
within 3 years & 0.67 & 0.62 & 0.73 \\
within 5 years & 0.80 & 0.75 & 0.85 \\
Number of individuals & 4,333 & 2,133 & 2,200 \\
\hline
\end{tabular}

Note. Reported are summary statistics obtained from couples in the Main Sample grouped by extent of family ties. The stratification considers couples above (strong) and below (weak) the median of our indicator of family ties computed as explained in Section 2 . 
Table 3: Pension reforms and family ties.

\begin{tabular}{|c|c|c|c|c|}
\hline & $\begin{array}{c}\text { Distance from } \\
\text { parents }\end{array}$ & $\begin{array}{l}\text { Having Sunday } \\
\text { lunch together }\end{array}$ & $\begin{array}{l}\text { Frequency of } \\
\text { meetings }\end{array}$ & $\begin{array}{c}\text { Frequency of } \\
\text { phone calls }\end{array}$ \\
\hline & (1) & (2) & (3) & (4) \\
\hline Post reform cohorts & $\begin{array}{l}-0.057 \\
(0.049)\end{array}$ & $\begin{array}{l}-0.031 \\
(0.029)\end{array}$ & $\begin{array}{c}0.004 \\
(0.038)\end{array}$ & $\begin{array}{c}0.019 \\
(0.039)\end{array}$ \\
\hline Age & $\begin{array}{l}-0.093 \\
(0.179)\end{array}$ & $\begin{array}{l}0.314^{* *} \\
(0.101)\end{array}$ & $\begin{array}{l}-0.300^{*} \\
(0.140)\end{array}$ & $\begin{array}{l}-0.320^{*} \\
(0.144)\end{array}$ \\
\hline Age squared & $\begin{array}{c}0.000 \\
(0.002)\end{array}$ & $\begin{array}{l}-0.003^{* *} \\
(0.001)\end{array}$ & $\begin{array}{c}0.002^{*} \\
(0.001)\end{array}$ & $\begin{array}{c}0.003^{*} \\
(0.001)\end{array}$ \\
\hline Cohort & $\begin{array}{l}-0.001 \\
(0.008)\end{array}$ & $\begin{array}{l}-0.004 \\
(0.005)\end{array}$ & $\begin{array}{c}0.011 \\
(0.007)\end{array}$ & $\begin{array}{c}0.014^{*} \\
(0.007)\end{array}$ \\
\hline Cohort squared & $\begin{array}{c}0.002 \\
(0.002)\end{array}$ & $\begin{array}{l}0.000 \\
(0.001)\end{array}$ & $\begin{array}{c}0.002 \\
(0.001)\end{array}$ & $\begin{array}{c}0.001 \\
(0.001)\end{array}$ \\
\hline Observations & 4,711 & 4,711 & 4,711 & 4,711 \\
\hline
\end{tabular}

Note. Reported are regression results of the extent of family ties on a dummy for cohorts of respondents affected by the reforms, see equation (1). Family ties are measured considering four indicators: (1) percentage of parents living in the same municipality of their offspring; (2) percentage of parents having lunch or dinner with offspring regularly on Sundays; (3) percentage of parents meeting offspring at least once a week; (4) percentage of parents calling offspring at least once a week. Robust standard errors in parentheses. See Section 3 for details on the estimation sample. ${ }^{*}$ significant at $10 \% ;{ }^{* *}$ significant at $5 \%$; ${ }^{* * *}$ significant at $1 \%$. 
Table 4: Pension eligibility and labor supply.

\begin{tabular}{|c|c|c|c|c|c|c|}
\hline & \multicolumn{3}{|c|}{ Males } & \multicolumn{3}{|c|}{ Females } \\
\hline & $\begin{array}{l}(1) \\
A l l\end{array}$ & $\begin{array}{c}(2) \\
\text { High school } \\
\text { dropouts }\end{array}$ & $\begin{array}{c}(3) \\
\text { High school } \\
\text { graduates }\end{array}$ & $\begin{array}{l}(4) \\
A l l\end{array}$ & $\begin{array}{l}(5) \\
\text { High school } \\
\text { dropouts }\end{array}$ & $\begin{array}{c}(6) \\
\text { High school } \\
\text { graduates }\end{array}$ \\
\hline \multicolumn{7}{|c|}{ Eligibility for pension benefits } \\
\hline Age 50 & $\begin{array}{l}-0.023 \\
(0.015)\end{array}$ & $\begin{array}{l}-0.043^{*} \\
(0.021)\end{array}$ & $\begin{array}{c}0.001 \\
(0.020)\end{array}$ & $\begin{array}{l}0.067^{* *} \\
(0.026)\end{array}$ & $\begin{array}{l}0.113^{* *} \\
(0.033)\end{array}$ & $\begin{array}{c}0.065 \\
(0.034)\end{array}$ \\
\hline Age 51 & $\begin{array}{l}-0.036^{* *} \\
(0.013)\end{array}$ & $\begin{array}{l}-0.079^{* * *} \\
(0.018)\end{array}$ & $\begin{array}{l}-0.017 \\
(0.020)\end{array}$ & $\begin{array}{c}0.026 \\
(0.021)\end{array}$ & $\begin{array}{l}-0.034 \\
(0.017)\end{array}$ & $\begin{array}{c}0.053 \\
(0.035)\end{array}$ \\
\hline Age 52 & $\begin{array}{l}-0.043^{* * *} \\
(0.012)\end{array}$ & $\begin{array}{l}-0.082^{* * *} \\
(0.016)\end{array}$ & $\begin{array}{l}-0.016 \\
(0.022)\end{array}$ & $\begin{array}{c}0.002 \\
(0.021)\end{array}$ & $\begin{array}{l}-0.049^{* *} \\
(0.017)\end{array}$ & $\begin{array}{c}0.019 \\
(0.037)\end{array}$ \\
\hline Age 53 & $\begin{array}{l}-0.060^{* * *} \\
(0.015)\end{array}$ & $\begin{array}{l}-0.095^{* * *} \\
(0.021)\end{array}$ & $\begin{array}{c}-0.016 \\
(0.025)\end{array}$ & $\begin{array}{c}0.000 \\
(0.022)\end{array}$ & $\begin{array}{l}-0.054^{* *} \\
(0.020)\end{array}$ & $\begin{array}{c}0.012 \\
(0.038)\end{array}$ \\
\hline Age 54 & $\begin{array}{l}-0.069^{* * *} \\
(0.018)\end{array}$ & $\begin{array}{l}-0.100^{* * * *} \\
(0.025)\end{array}$ & $\begin{array}{c}0.003 \\
(0.025)\end{array}$ & $\begin{array}{l}-0.004 \\
(0.022)\end{array}$ & $\begin{array}{l}-0.047^{*} \\
(0.023)\end{array}$ & $\begin{array}{l}-0.016 \\
(0.038)\end{array}$ \\
\hline Age 55 & $\begin{array}{l}-0.083^{* * *} \\
(0.021)\end{array}$ & $\begin{array}{l}-0.112^{* * * *} \\
(0.029)\end{array}$ & $\begin{array}{l}-0.006 \\
(0.016)\end{array}$ & $\begin{array}{l}-0.012 \\
(0.021)\end{array}$ & $\begin{array}{l}-0.049 * \\
(0.024)\end{array}$ & $\begin{array}{l}-0.011 \\
(0.026)\end{array}$ \\
\hline Age 56 & $\begin{array}{l}-0.119^{* * *} \\
(0.023)\end{array}$ & $\begin{array}{l}-0.136^{* * *} \\
(0.032)\end{array}$ & $\begin{array}{l}-0.059^{* *} \\
(0.020)\end{array}$ & $\begin{array}{l}-0.072^{* * *} \\
(0.021)\end{array}$ & $\begin{array}{l}-0.103^{* * *} \\
(0.023)\end{array}$ & $\begin{array}{l}-0.088^{* *} \\
(0.027)\end{array}$ \\
\hline Age 57 & $\begin{array}{l}-0.125^{* * *} \\
(0.026)\end{array}$ & $\begin{array}{l}-0.125^{* *} \\
(0.038)\end{array}$ & $\begin{array}{l}-0.125^{* * *} \\
(0.025)\end{array}$ & $\begin{array}{l}-0.076^{* * *} \\
(0.021)\end{array}$ & $\begin{array}{l}-0.105^{* * *} \\
(0.022)\end{array}$ & $\begin{array}{l}-0.101^{* *} \\
(0.036)\end{array}$ \\
\hline Age 58 & $\begin{array}{l}-0.154^{* * *} \\
(0.029)\end{array}$ & & $\begin{array}{l}-0.149^{* * *} \\
(0.026)\end{array}$ & $\begin{array}{l}-0.123^{* *} \\
(0.037)\end{array}$ & & $\begin{array}{l}-0.097^{* *} \\
(0.036)\end{array}$ \\
\hline Age 59 & $\begin{array}{l}-0.184^{* * *} \\
(0.033)\end{array}$ & & $\begin{array}{l}-0.175^{* * *} \\
(0.031)\end{array}$ & $\begin{array}{l}-0.083^{*} \\
(0.041)\end{array}$ & & $\begin{array}{l}-0.064 \\
(0.041)\end{array}$ \\
\hline Age 60 & $\begin{array}{l}-0.171^{* * *} \\
(0.030)\end{array}$ & & $\begin{array}{l}-0.166^{* * *} \\
(0.030)\end{array}$ & $\begin{array}{c}0.011 \\
(0.036)\end{array}$ & & $\begin{array}{c}0.007 \\
(0.038)\end{array}$ \\
\hline Observations & 48,749 & 31,036 & 17,713 & 36,429 & 23,659 & 12,770 \\
\hline
\end{tabular}

Note. Estimates of equation (2) from the Sample of Grandparents by gender and educational attainment. The specification controls for a quadratic polynomial in age and a full set of dummies for region of residence and educational attainment. Standard errors are clustered by cohort, education and sector of activity. See Section 4 for details. ${ }^{*}$ significant at $10 \% ;{ }^{* *}$ significant at $5 \%$; ${ }^{* *}$ significant at $1 \%$. 


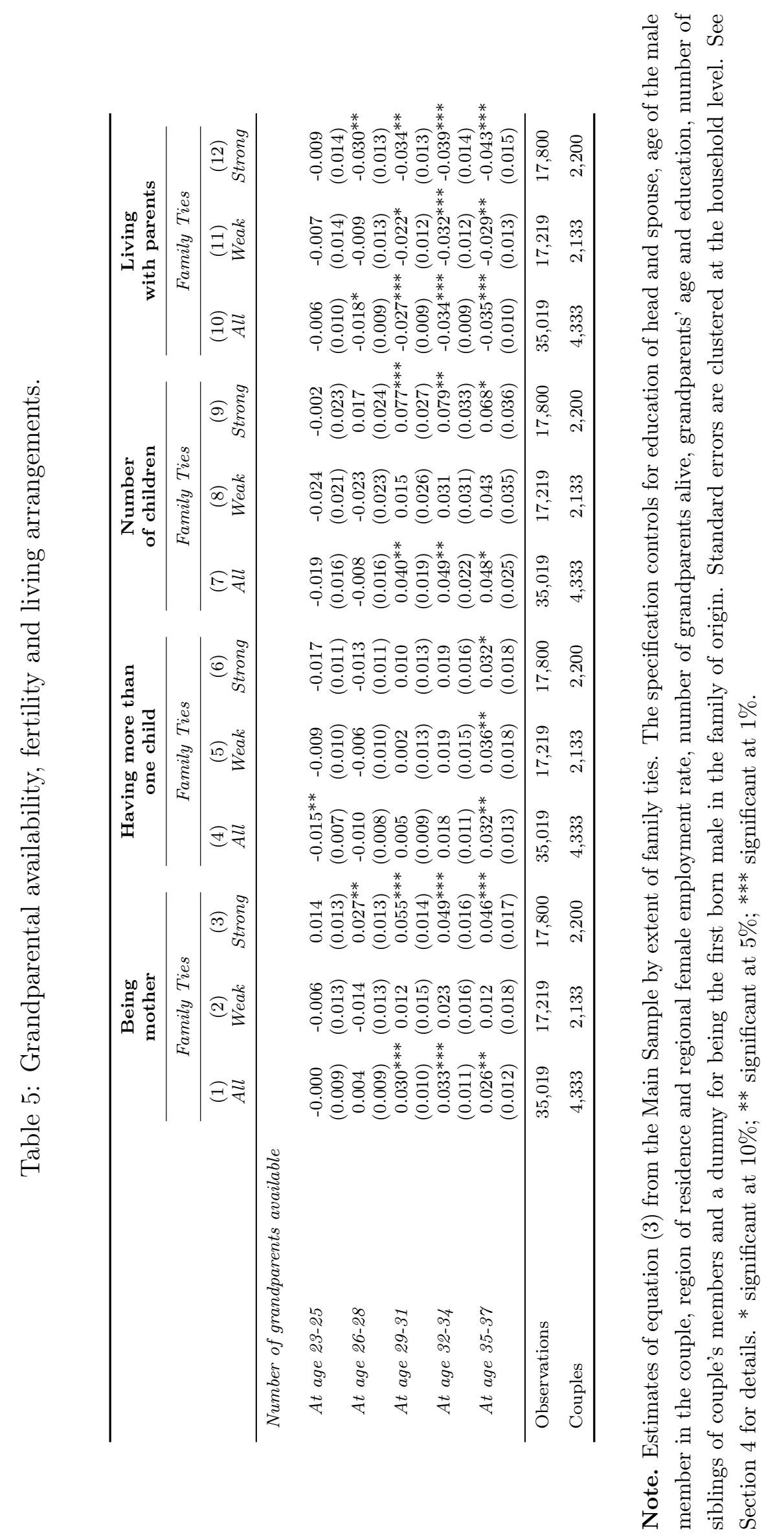


Table 6: Preferences as opposed to lack of resources.

\begin{tabular}{|c|c|c|c|c|c|c|c|c|c|}
\hline & \multicolumn{9}{|c|}{ Family resources proxied by: } \\
\hline & \multirow{2}{*}{\multicolumn{3}{|c|}{$\frac{\text { Educational attainment }}{\text { Family Ties }}$}} & \multirow{2}{*}{\multicolumn{3}{|c|}{$\begin{array}{l}\text { House size } \\
\text { Family Ties }\end{array}$}} & \multirow{2}{*}{\multicolumn{3}{|c|}{$\frac{\text { Kindergarten coverage }}{\text { Family Ties }}$}} \\
\hline & & & & & & & & & \\
\hline & $\begin{array}{l}(1) \\
\text { All }\end{array}$ & $\begin{array}{c}(2) \\
\text { Weak }\end{array}$ & $\begin{array}{c}(3) \\
\text { Strong }\end{array}$ & $\begin{array}{l}(4) \\
\text { All }\end{array}$ & $\begin{array}{c}(5) \\
\text { Weak }\end{array}$ & $\begin{array}{c}(6) \\
\text { Strong }\end{array}$ & $\begin{array}{l}(7) \\
\text { All }\end{array}$ & $\begin{array}{c}(8) \\
\text { Weak }\end{array}$ & $\begin{array}{c}(9) \\
\text { Strong }\end{array}$ \\
\hline \multicolumn{10}{|c|}{$\begin{array}{c}\text { Number of grandparents available } \\
\text { in low wealth households }\end{array}$} \\
\hline At age 23-25 & $\begin{array}{l}-0.004 \\
(0.010)\end{array}$ & $\begin{array}{l}-0.006 \\
(0.014)\end{array}$ & $\begin{array}{c}0.006 \\
(0.014)\end{array}$ & $\begin{array}{l}-0.002 \\
(0.011)\end{array}$ & $\begin{array}{l}-0.009 \\
(0.015)\end{array}$ & $\begin{array}{c}0.011 \\
(0.016)\end{array}$ & $\begin{array}{c}0.005 \\
(0.011)\end{array}$ & $\begin{array}{c}0.006 \\
(0.016)\end{array}$ & $\begin{array}{c}0.013 \\
(0.015)\end{array}$ \\
\hline At age 26-28 & $\begin{array}{c}0.009 \\
(0.010)\end{array}$ & $\begin{array}{l}-0.006 \\
(0.015)\end{array}$ & $\begin{array}{l}0.029^{* *} \\
(0.014)\end{array}$ & $\begin{array}{c}0.012 \\
(0.011)\end{array}$ & $\begin{array}{l}-0.010 \\
(0.015)\end{array}$ & $\begin{array}{l}0.043^{* * *} \\
(0.016)\end{array}$ & $\begin{array}{c}0.017 \\
(0.011)\end{array}$ & $\begin{array}{c}0.005 \\
(0.016)\end{array}$ & $\begin{array}{l}0.032^{* *} \\
(0.014)\end{array}$ \\
\hline At age 29-31 & $\begin{array}{l}0.031^{* * *} \\
(0.011)\end{array}$ & $\begin{array}{c}0.018 \\
(0.016)\end{array}$ & $\begin{array}{l}0.050^{* * *} \\
(0.015)\end{array}$ & $\begin{array}{l}0.035^{* * *} \\
(0.012)\end{array}$ & $\begin{array}{c}0.012 \\
(0.016)\end{array}$ & $\begin{array}{l}0.068^{* * * *} \\
(0.016)\end{array}$ & $\begin{array}{l}0.038^{* * *} \\
(0.011)\end{array}$ & $\begin{array}{c}0.026 \\
(0.017)\end{array}$ & $\begin{array}{l}0.053^{* * *} \\
(0.015)\end{array}$ \\
\hline At age 32-34 & $\begin{array}{l}0.026^{* *} \\
(0.012)\end{array}$ & $\begin{array}{c}0.019 \\
(0.016)\end{array}$ & $\begin{array}{l}0.038^{* *} \\
(0.016)\end{array}$ & $\begin{array}{l}0.029^{* *} \\
(0.012)\end{array}$ & $\begin{array}{c}0.013 \\
(0.017)\end{array}$ & $\begin{array}{l}0.053^{* * *} \\
(0.017)\end{array}$ & $\begin{array}{l}0.038^{* * *} \\
(0.012)\end{array}$ & $\begin{array}{l}0.038^{* *} \\
(0.018)\end{array}$ & $\begin{array}{l}0.042^{* *} \\
(0.016)\end{array}$ \\
\hline At age $35-37$ & $\begin{array}{c}0.015 \\
(0.013)\end{array}$ & $\begin{array}{c}0.002 \\
(0.018)\end{array}$ & $\begin{array}{c}0.033^{*} \\
(0.018)\end{array}$ & $\begin{array}{c}0.020 \\
(0.013)\end{array}$ & $\begin{array}{c}0.001 \\
(0.019)\end{array}$ & $\begin{array}{l}0.046^{* *} \\
(0.018)\end{array}$ & $\begin{array}{l}0.026^{* *} \\
(0.013)\end{array}$ & $\begin{array}{l}0.023 \\
(0.019)\end{array}$ & $\begin{array}{l}0.036^{* *} \\
(0.018)\end{array}$ \\
\hline \multicolumn{10}{|c|}{$\begin{array}{l}\text { Number of grandparents available } \\
\text { in high wealth households }\end{array}$} \\
\hline At age 23-25 & $\begin{array}{c}0.008 \\
(0.011)\end{array}$ & $\begin{array}{l}-0.003 \\
(0.017)\end{array}$ & $\begin{array}{c}0.028^{*} \\
(0.015)\end{array}$ & $\begin{array}{c}0.003 \\
(0.010)\end{array}$ & $\begin{array}{l}-0.000 \\
(0.015)\end{array}$ & $\begin{array}{c}0.017 \\
(0.015)\end{array}$ & $\begin{array}{l}-0.005 \\
(0.010)\end{array}$ & $\begin{array}{l}-0.013 \\
(0.014)\end{array}$ & $\begin{array}{c}0.017 \\
(0.016)\end{array}$ \\
\hline At age 26-28 & $\begin{array}{l}-0.016 \\
(0.011)\end{array}$ & $\begin{array}{l}-0.037^{* *} \\
(0.016)\end{array}$ & $\begin{array}{c}0.012 \\
(0.016)\end{array}$ & $\begin{array}{l}-0.003 \\
(0.010)\end{array}$ & $\begin{array}{l}-0.017 \\
(0.015)\end{array}$ & $\begin{array}{l}0.016 \\
(0.014)\end{array}$ & $\begin{array}{l}-0.011 \\
(0.010)\end{array}$ & $\begin{array}{l}-0.029^{* *} \\
(0.014)\end{array}$ & $\begin{array}{c}0.020 \\
(0.015)\end{array}$ \\
\hline At age 29-31 & $\begin{array}{c}0.021^{*} \\
(0.012)\end{array}$ & $\begin{array}{l}-0.006 \\
(0.018)\end{array}$ & $\begin{array}{l}0.056^{* * *} \\
(0.017)\end{array}$ & $\begin{array}{l}0.024^{* *} \\
(0.011)\end{array}$ & $\begin{array}{c}0.012 \\
(0.016)\end{array}$ & $\begin{array}{l}0.041^{* * *} \\
(0.016)\end{array}$ & $\begin{array}{l}0.023^{* *} \\
(0.011)\end{array}$ & $\begin{array}{c}0.003 \\
(0.016)\end{array}$ & $\begin{array}{l}0.058^{* * *} \\
(0.016)\end{array}$ \\
\hline At age 32-34 & $\begin{array}{l}0.048^{* * *} \\
(0.013)\end{array}$ & $\begin{array}{c}0.034^{*} \\
(0.019)\end{array}$ & $\begin{array}{l}0.068^{* * *} \\
(0.019)\end{array}$ & $\begin{array}{l}0.036^{* * *} \\
(0.012)\end{array}$ & $\begin{array}{l}0.036^{* *} \\
(0.017)\end{array}$ & $\begin{array}{l}0.041^{* *} \\
(0.017)\end{array}$ & $\begin{array}{l}0.029^{* *} \\
(0.012)\end{array}$ & $\begin{array}{c}0.013 \\
(0.017)\end{array}$ & $\begin{array}{l}0.059^{* * *} \\
(0.017)\end{array}$ \\
\hline At age $35-37$ & $\begin{array}{l}0.054^{* * *} \\
(0.015)\end{array}$ & $\begin{array}{c}0.039^{*} \\
(0.020)\end{array}$ & $\begin{array}{l}0.075^{* * *} \\
(0.021)\end{array}$ & $\begin{array}{c}0.033^{* *} \\
(0.014) \\
\end{array}$ & $\begin{array}{c}0.030 \\
(0.019) \\
\end{array}$ & $\begin{array}{l}0.042^{* *} \\
(0.019)\end{array}$ & $\begin{array}{l}0.028^{* *} \\
(0.013)\end{array}$ & $\begin{array}{c}0.007 \\
(0.019) \\
\end{array}$ & $\begin{array}{l}0.064^{* * *} \\
(0.019)\end{array}$ \\
\hline Observations & 35,019 & 17,219 & 17,800 & 35,019 & 17,219 & 17,800 & 35,019 & 17,219 & 17,800 \\
\hline Couples & 4,333 & 2,133 & 2,200 & 4,333 & 2,133 & 2,200 & 4,333 & 2,133 & 2,200 \\
\hline
\end{tabular}

Note. Estimates of equation (3) from the Main Sample by extent of family ties and household resources. The first panel considers the highest educational attainment of the head and the spouse in the couple, and classifies households above and below high school diploma. The central panel considers house size above or below its area average. The last panel splits households in areas where kindergarten coverage is above or below the national median. The specification controls for education of head and spouse, age of the male member in the couple, region of residence and regional female employment rate, number of grandparents alive, grandparents' age and education, number of siblings of couples members and a dummy for being the first born male in the family of origin. Standard errors are clustered at the household level. See Section 4 for details. ${ }^{*}$ significant at $10 \% ;{ }^{* *}$ significant at $5 \% ;{ }^{* * *}$ significant at $1 \%$. 
Table 7: Grandparental availability breakdown by origin and gender.

\begin{tabular}{|c|c|c|c|c|c|c|c|c|c|}
\hline & \multicolumn{3}{|c|}{ Family Ties } & \multicolumn{3}{|c|}{ Family Ties } & \multicolumn{3}{|c|}{ Family Ties } \\
\hline & $\begin{array}{l}(1) \\
\text { All }\end{array}$ & $\begin{array}{l}(2) \\
\text { Weak }\end{array}$ & $\begin{array}{c}(3) \\
\text { Strong }\end{array}$ & $\begin{array}{l}(4) \\
\text { All }\end{array}$ & $\begin{array}{c}(5) \\
\text { Weak }\end{array}$ & $\begin{array}{c}(6) \\
\text { Strong }\end{array}$ & $\begin{array}{l}(7) \\
\text { All }\end{array}$ & $\begin{array}{c}(8) \\
\text { Weak }\end{array}$ & $\begin{array}{c}(9) \\
\text { Strong }\end{array}$ \\
\hline & \multicolumn{3}{|c|}{$\begin{array}{c}\text { Number of } \\
\text { grandmothers available }\end{array}$} & \multicolumn{3}{|c|}{$\begin{array}{l}\text { Number of maternal } \\
\text { grandparents available }\end{array}$} & \multicolumn{3}{|c|}{$\begin{array}{c}\text { Maternal } \\
\text { grandmother available }\end{array}$} \\
\hline At age $23-25$ & $\begin{array}{l}0.017 \\
(0.019)\end{array}$ & $\begin{array}{c}0.008 \\
(0.027)\end{array}$ & $\begin{array}{l}0.028 \\
(0.025)\end{array}$ & $\begin{array}{c}0.014 \\
(0.017)\end{array}$ & $\begin{array}{c}0.007 \\
(0.023)\end{array}$ & $\begin{array}{c}0.038 \\
(0.024)\end{array}$ & $\begin{array}{l}0.060^{* *} \\
(0.029)\end{array}$ & $\begin{array}{c}0.056 \\
(0.039)\end{array}$ & $\begin{array}{c}0.075^{*} \\
(0.041)\end{array}$ \\
\hline At age 26-28 & $\begin{array}{c}0.031 \\
(0.019)\end{array}$ & $\begin{array}{c}0.027 \\
(0.027)\end{array}$ & $\begin{array}{c}0.044^{*} \\
(0.026)\end{array}$ & $\begin{array}{l}-0.001 \\
(0.017)\end{array}$ & $\begin{array}{l}-0.036 \\
(0.023)\end{array}$ & $\begin{array}{l}0.048^{* *} \\
(0.024)\end{array}$ & $\begin{array}{c}0.034 \\
(0.028)\end{array}$ & $\begin{array}{c}0.019 \\
(0.037)\end{array}$ & $\begin{array}{c}0.069^{*} \\
(0.041)\end{array}$ \\
\hline At age 29-31 & $\begin{array}{l}0.067^{* * *} \\
(0.021)\end{array}$ & $\begin{array}{c}0.054^{*} \\
(0.029)\end{array}$ & $\begin{array}{l}0.093^{* * *} \\
(0.029)\end{array}$ & $\begin{array}{l}0.037^{* *} \\
(0.019)\end{array}$ & $\begin{array}{l}-0.010 \\
(0.025)\end{array}$ & $\begin{array}{l}0.103^{* * *} \\
(0.027)\end{array}$ & $\begin{array}{l}0.075^{* *} \\
(0.029)\end{array}$ & $\begin{array}{c}0.030 \\
(0.040)\end{array}$ & $\begin{array}{l}0.142^{* * *} \\
(0.041)\end{array}$ \\
\hline At age $32-34$ & $\begin{array}{l}0.063^{* *} \\
(0.025)\end{array}$ & $\begin{array}{c}0.047 \\
(0.036)\end{array}$ & $\begin{array}{l}0.093^{* * *} \\
(0.034)\end{array}$ & $\begin{array}{l}0.036 \\
(0.022)\end{array}$ & $\begin{array}{c}0.026 \\
(0.032)\end{array}$ & $\begin{array}{c}0.057^{*} \\
(0.030)\end{array}$ & $\begin{array}{l}0.071^{* *} \\
(0.033)\end{array}$ & $\begin{array}{c}0.037 \\
(0.046)\end{array}$ & $\begin{array}{l}0.118^{* *} \\
(0.046)\end{array}$ \\
\hline \multirow[t]{2}{*}{ At age $35-37$} & $\begin{array}{c}0.023 \\
(0.037)\end{array}$ & $\begin{array}{l}-0.005 \\
(0.052)\end{array}$ & $\begin{array}{c}0.064 \\
(0.051)\end{array}$ & $\begin{array}{c}0.071^{*} \\
(0.038)\end{array}$ & $\begin{array}{c}0.068 \\
(0.053)\end{array}$ & $\begin{array}{c}0.073 \\
(0.046)\end{array}$ & $\begin{array}{c}0.068 \\
(0.044)\end{array}$ & $\begin{array}{c}0.027 \\
(0.061)\end{array}$ & $\begin{array}{c}0.123^{*} \\
(0.065)\end{array}$ \\
\hline & \multicolumn{3}{|c|}{$\begin{array}{c}\text { Number of } \\
\text { grandfathers available }\end{array}$} & \multicolumn{3}{|c|}{$\begin{array}{l}\text { Number of paternal } \\
\text { grandparents available }\end{array}$} & \multicolumn{3}{|c|}{$\begin{array}{c}\text { Maternal } \\
\text { grandfather available }\end{array}$} \\
\hline At age $23-25$ & $\begin{array}{l}-0.019 \\
(0.019)\end{array}$ & $\begin{array}{l}-0.022 \\
(0.026)\end{array}$ & $\begin{array}{l}-0.001 \\
(0.026)\end{array}$ & $\begin{array}{l}-0.014 \\
(0.015)\end{array}$ & $\begin{array}{l}-0.016 \\
(0.022)\end{array}$ & $\begin{array}{l}-0.010 \\
(0.021)\end{array}$ & $\begin{array}{l}-0.035 \\
(0.027)\end{array}$ & $\begin{array}{l}-0.051 \\
(0.036)\end{array}$ & $\begin{array}{l}-0.000 \\
(0.040)\end{array}$ \\
\hline At age 26-28 & $\begin{array}{l}-0.020 \\
(0.020)\end{array}$ & $\begin{array}{l}-0.049^{*} \\
(0.028)\end{array}$ & $\begin{array}{c}0.018 \\
(0.028)\end{array}$ & $\begin{array}{l}0.017 \\
(0.017)\end{array}$ & $\begin{array}{c}0.022 \\
(0.023)\end{array}$ & $\begin{array}{c}0.015 \\
(0.023)\end{array}$ & $\begin{array}{l}-0.031 \\
(0.029)\end{array}$ & $\begin{array}{l}-0.089^{* *} \\
(0.039)\end{array}$ & $\begin{array}{c}0.034 \\
(0.041)\end{array}$ \\
\hline At age 29-31 & $\begin{array}{c}0.004 \\
(0.024)\end{array}$ & $\begin{array}{l}-0.007 \\
(0.032)\end{array}$ & $\begin{array}{c}0.020 \\
(0.035)\end{array}$ & $\begin{array}{c}0.044^{* *} \\
(0.020)\end{array}$ & $\begin{array}{l}0.072^{* * *} \\
(0.026)\end{array}$ & $\begin{array}{c}0.014 \\
(0.029)\end{array}$ & $\begin{array}{c}0.005 \\
(0.033)\end{array}$ & $\begin{array}{l}-0.044 \\
(0.044)\end{array}$ & $\begin{array}{c}0.062 \\
(0.048)\end{array}$ \\
\hline At age 32-34 & $\begin{array}{l}-0.029 \\
(0.033)\end{array}$ & $\begin{array}{c}0.011 \\
(0.044)\end{array}$ & $\begin{array}{l}-0.081^{*} \\
(0.048)\end{array}$ & $\begin{array}{c}0.021 \\
(0.026)\end{array}$ & $\begin{array}{c}0.040 \\
(0.030)\end{array}$ & $\begin{array}{c}0.009 \\
(0.045)\end{array}$ & $\begin{array}{l}-0.018 \\
(0.043)\end{array}$ & $\begin{array}{c}0.014 \\
(0.061)\end{array}$ & $\begin{array}{l}-0.051 \\
(0.058)\end{array}$ \\
\hline At age $35-37$ & $\begin{array}{c}0.027 \\
(0.065) \\
\end{array}$ & $\begin{array}{c}0.081 \\
(0.077) \\
\end{array}$ & $\begin{array}{l}-0.118 \\
(0.106) \\
\end{array}$ & $\begin{array}{l}-0.025 \\
(0.041) \\
\end{array}$ & $\begin{array}{l}-0.006 \\
(0.050) \\
\end{array}$ & $\begin{array}{l}-0.047 \\
(0.065) \\
\end{array}$ & $\begin{array}{c}0.089 \\
(0.091) \\
\end{array}$ & $\begin{array}{c}0.164 \\
(0.110) \\
\end{array}$ & $\begin{array}{c}-0.119 \\
(0.090) \\
\end{array}$ \\
\hline Observations & 15,043 & 7,742 & 7,301 & 15,043 & 7,742 & 7,301 & 15,043 & 7,742 & 7,301 \\
\hline Couples & 1,867 & 958 & 909 & 1,867 & 958 & 909 & 1,867 & 958 & 909 \\
\hline
\end{tabular}

Note. Estimates of equation (3) from the Main Sample by origin and gender of grandparents. Only couples with all grandparents alive are considered. The first panel considers a breakdown by gender of grandparents. The central panel considers a breakdown by family of origin, distinguishing between maternal and paternal grandparents. The last panel considers a breakdown by gender of maternal grandparents. The specification controls for education of head and spouse, age of the male member in the couple, region of residence and regional female employment rate, grandparents' age and education, number of siblings of couples members and a dummy for being the first born male in the family of origin. Standard errors are clustered at the household level. See Section 5 for details. ${ }^{*}$ significant at $10 \%$; ${ }^{* *}$ significant at $5 \%$; ${ }^{* * *}$ significant at $1 \%$. 


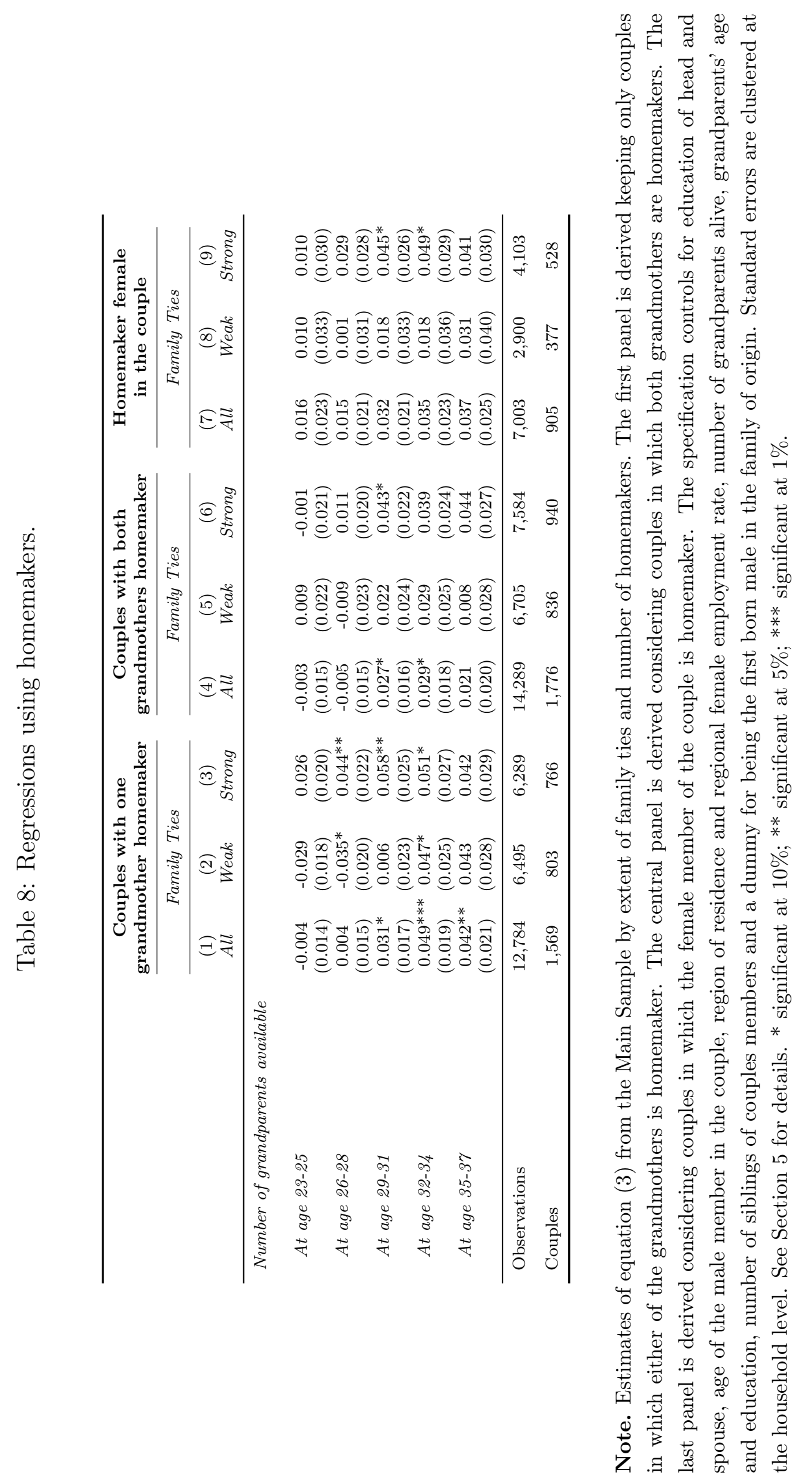


Table 9: Effects on Employment and Education.

\begin{tabular}{|c|c|c|c|c|c|c|}
\hline & \multicolumn{3}{|c|}{ Employment } & \multicolumn{3}{|c|}{ College Graduate } \\
\hline & \multicolumn{3}{|c|}{ Family Ties } & \multicolumn{3}{|c|}{ Family Ties } \\
\hline & $\begin{array}{l}(1) \\
\text { All }\end{array}$ & $\begin{array}{c}(2) \\
\text { Weak }\end{array}$ & $\begin{array}{c}(3) \\
\text { Strong }\end{array}$ & $\begin{array}{l}(4) \\
\text { All }\end{array}$ & $\begin{array}{c}(5) \\
\text { Weak }\end{array}$ & $\begin{array}{c}(6) \\
\text { Strong }\end{array}$ \\
\hline \multicolumn{7}{|c|}{ Number of grandparents available } \\
\hline At age 23-25 & $\begin{array}{c}0.020^{*} \\
(0.010)\end{array}$ & $\begin{array}{c}0.006 \\
(0.014)\end{array}$ & $\begin{array}{l}0.031^{* *} \\
(0.015)\end{array}$ & $\begin{array}{l}0.022^{* * *} \\
(0.005)\end{array}$ & $\begin{array}{l}0.018^{* *} \\
(0.008)\end{array}$ & $\begin{array}{l}0.024^{* * *} \\
(0.007)\end{array}$ \\
\hline At age 26-28 & $\begin{array}{c}0.002 \\
(0.010)\end{array}$ & $\begin{array}{c}0.003 \\
(0.014)\end{array}$ & $\begin{array}{l}0.001 \\
(0.014)\end{array}$ & $\begin{array}{l}0.014^{* * *} \\
(0.005)\end{array}$ & $\begin{array}{c}0.012^{*} \\
(0.007)\end{array}$ & $\begin{array}{l}0.014^{* *} \\
(0.006)\end{array}$ \\
\hline At age 29-31 & $\begin{array}{c}0.002 \\
(0.011)\end{array}$ & $\begin{array}{l}-0.004 \\
(0.015)\end{array}$ & $\begin{array}{c}0.007 \\
(0.016)\end{array}$ & $\begin{array}{l}0.011^{* *} \\
(0.005)\end{array}$ & $\begin{array}{c}0.010 \\
(0.007)\end{array}$ & $\begin{array}{c}0.010 \\
(0.007)\end{array}$ \\
\hline At age $32-34$ & $\begin{array}{l}-0.004 \\
(0.013)\end{array}$ & $\begin{array}{l}-0.018 \\
(0.017)\end{array}$ & $\begin{array}{c}0.010 \\
(0.018)\end{array}$ & $\begin{array}{l}0.014^{* *} \\
(0.005)\end{array}$ & $\begin{array}{c}0.010 \\
(0.008)\end{array}$ & $\begin{array}{l}0.018^{* *} \\
(0.007)\end{array}$ \\
\hline At age 35-37 & $\begin{array}{l}-0.005 \\
(0.014)\end{array}$ & $\begin{array}{l}-0.015 \\
(0.019)\end{array}$ & $\begin{array}{c}0.005 \\
(0.020)\end{array}$ & $\begin{array}{l}0.015^{* *} \\
(0.006)\end{array}$ & $\begin{array}{c}0.012 \\
(0.009)\end{array}$ & $\begin{array}{l}0.019^{* * *} \\
(0.007)\end{array}$ \\
\hline Observations & 35,019 & 17,219 & 17,800 & 35,019 & 17,219 & 17,800 \\
\hline Couples & 4,333 & 2,133 & 2,200 & 4,333 & 2,133 & 2,200 \\
\hline
\end{tabular}

Note. Estimates of equation (3) from the Main Sample by extent of family ties. The specification controls for education of head and spouse, age of the male member in the couple, region of residence and regional female employment rate, number of grandparents alive, grandparents' age and education, number of siblings of couple's members and a dummy for being the first born male in the family of origin. Standard errors are clustered at the household level. See Section 5 for details. * significant at $10 \%$; ** significant at $5 \%$; *** significant at $1 \%$. 
Figure 1: Minimum retirement age as implied by old age and seniority criteria.
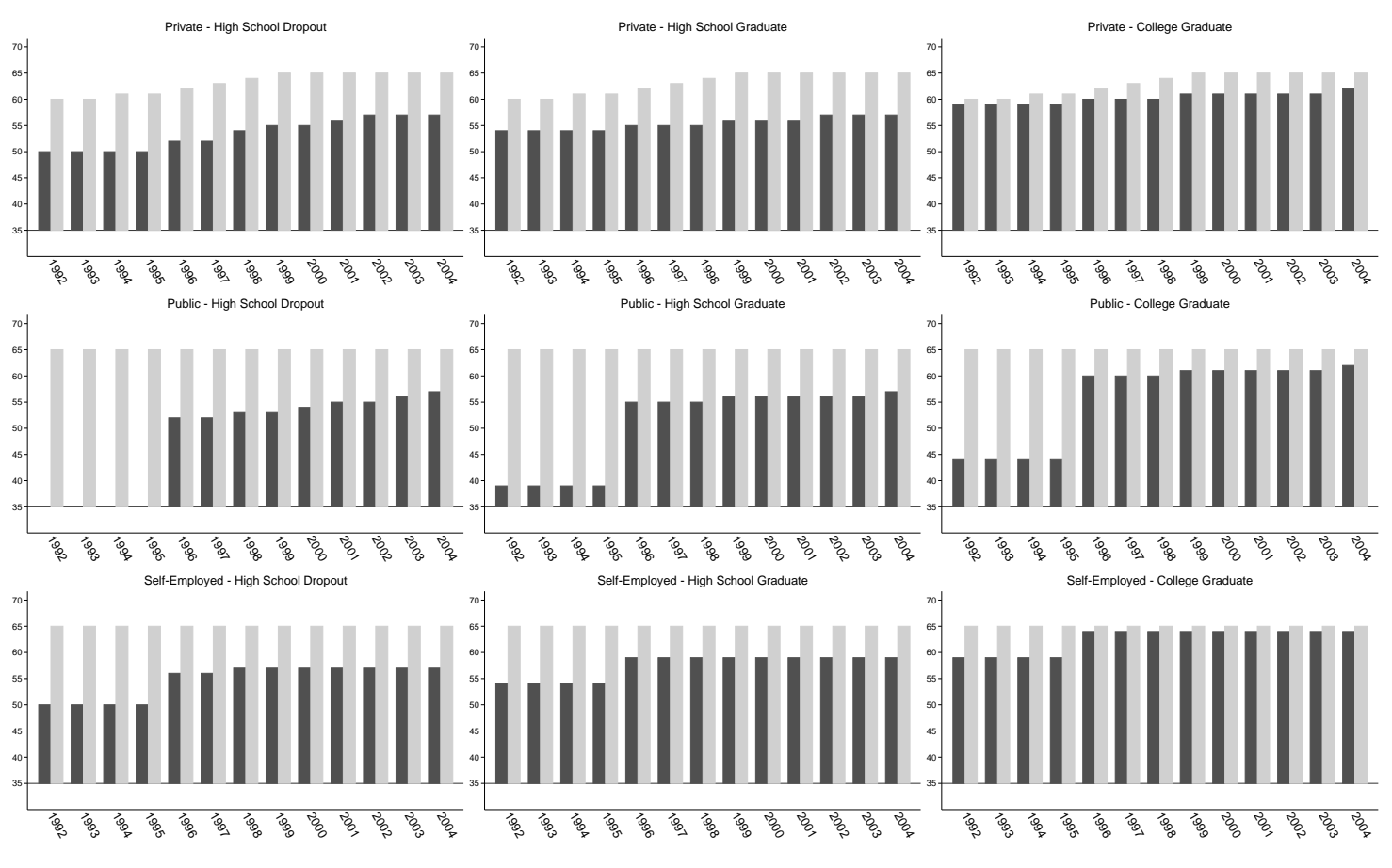

- Seniority pensions Old age pensions
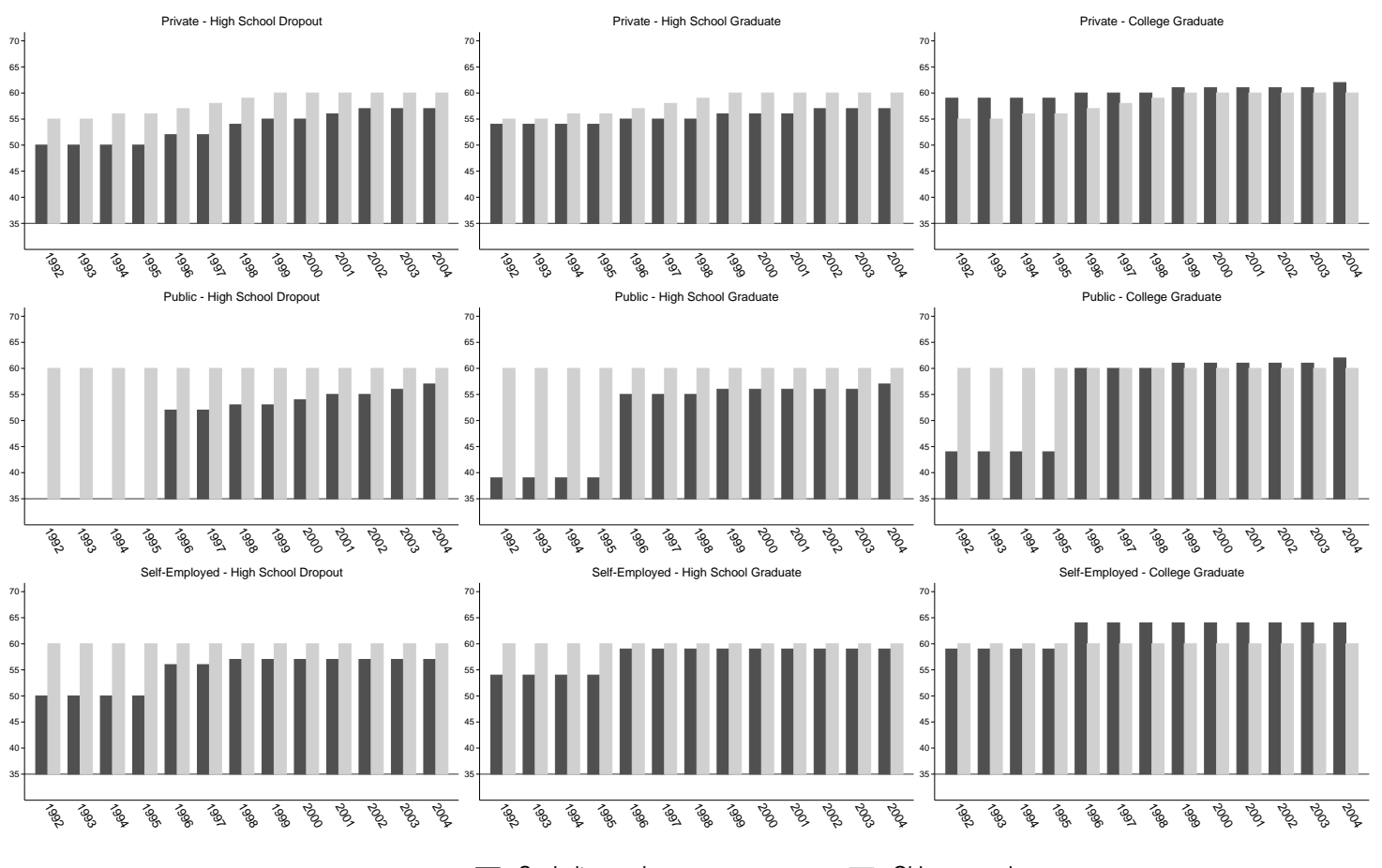

- Seniority pensions Old age pensions

Note. The figures set out the comparison of consecutive cohorts of male (top panel) and female (bottom panel) individuals indexed by the year in which they reach age 50. A breakdown is considered by sector of activity and educational attainment. See Section 3 for details on computation. 
Figure 2: Policy changes to minimum retirement age.
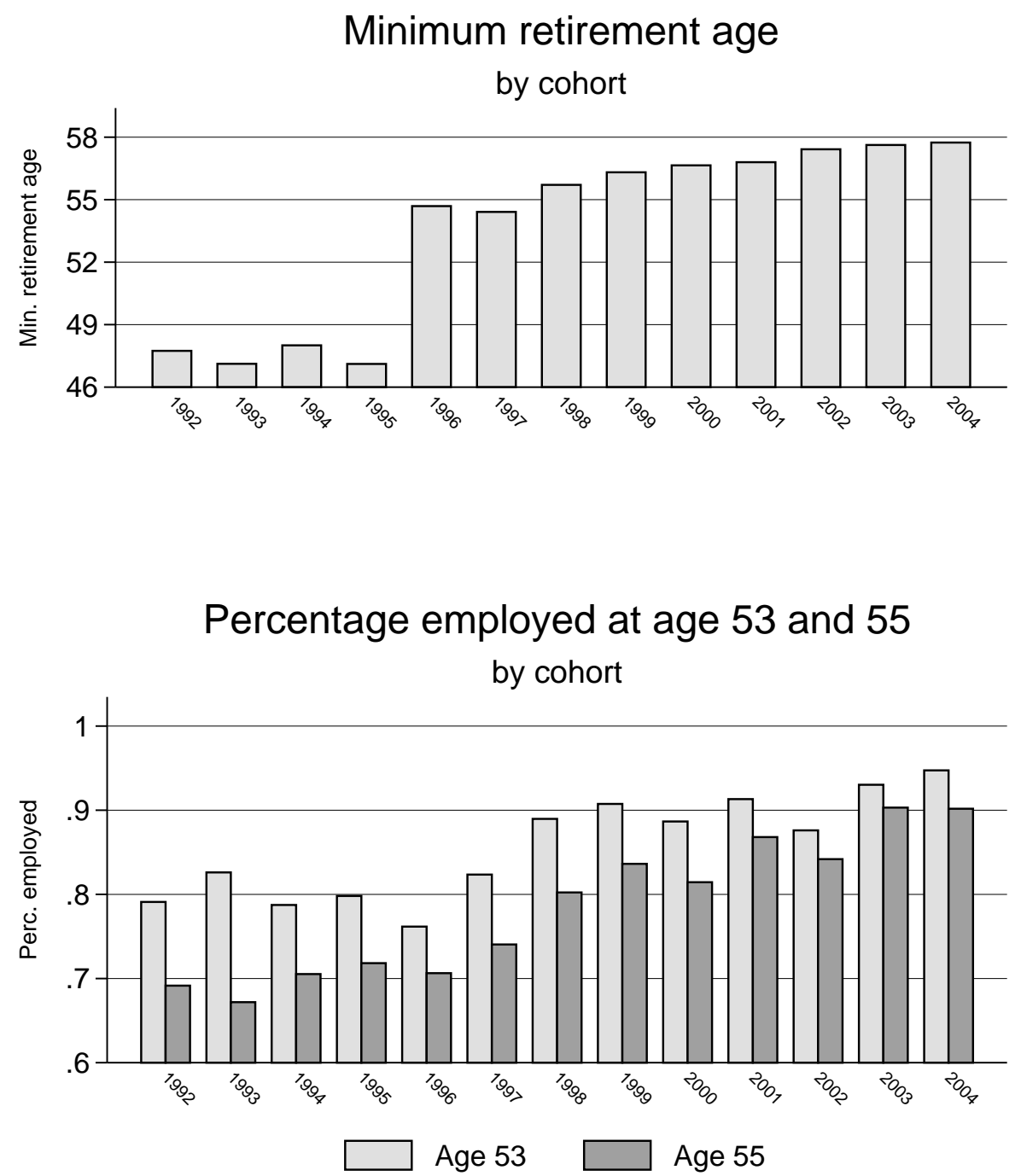

Note. The figures set out the comparison of consecutive cohorts of male individuals indexed by the year in which they reach age 50. Reported in the top panel is minimum retirement age by cohort averaged across individuals in the Sample of Parents. For the same individuals, the bottom panel reports the percentage at work at age 53 and age 55 . See Section 3 for details on computation. 
Figure 3: Average number of grandparents available.

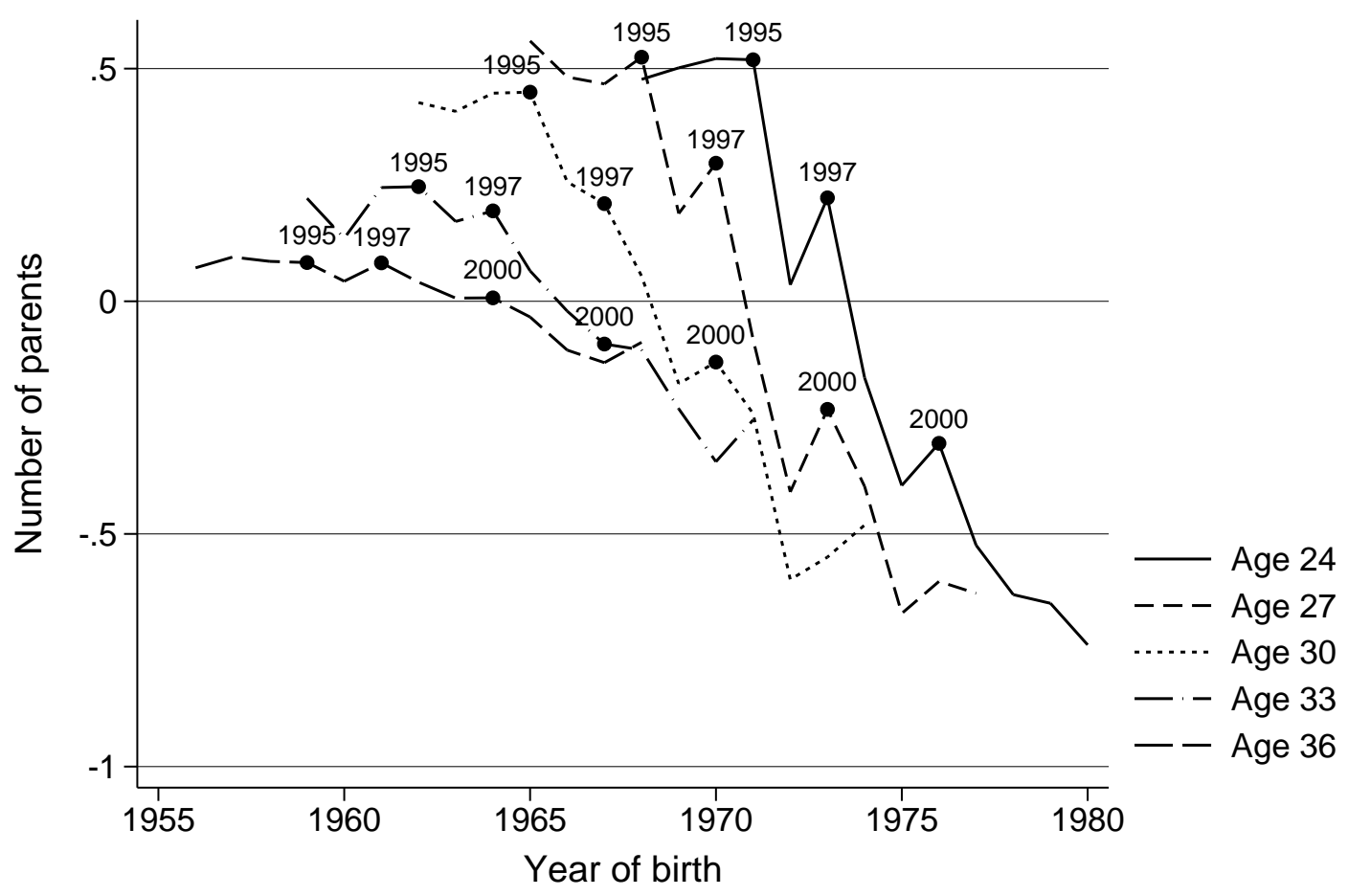

Note. The horizontal axis refers to the cohort of birth of the female member of the couple in the Main Sample. The vertical axis reports the average residualized total number of parents and parents in law at different ages of the female member. Residuals are computed with respect to age and education of parents. See Section 3 for details. 
Figure 4: Profiles for official cohort fertility rates (National Statistical Office 1970-2012).

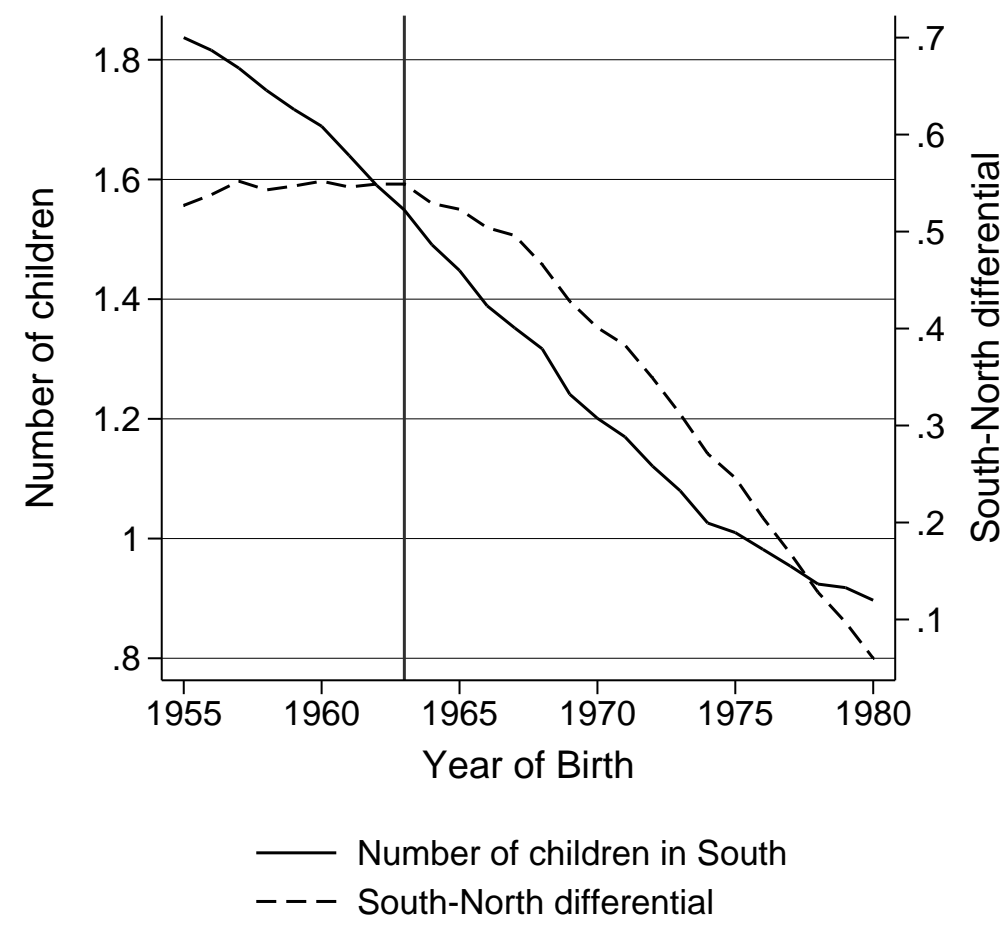

Note. Fertility rates at age 32 computed using data from the Italian National Statistical Office. The horizontal axis runs over years of birth. The left hand sided vertical axis reports the average number of children at age 32 by cohort of birth for females in Southern Italy. The right hand sided vertical axis reports the North-South differential, namely the difference in the average number of children between Southern and Northern regions. The vertical line refers to the cohort of those born in 1962 and aged 32 in 1995. This is the last cohort of females who reached age 32 in the period before pension reforms. 


\section{A Additional material}

Table A.1: Grandparental availability, inter-generational fertility and living arrangements (alternative definition of family ties).

\begin{tabular}{|c|c|c|c|c|c|c|}
\hline & \multicolumn{3}{|c|}{$\begin{array}{l}\text { Being } \\
\text { mother }\end{array}$} & \multicolumn{3}{|c|}{$\begin{array}{l}\text { Having more than } \\
\text { one child }\end{array}$} \\
\hline & \multicolumn{3}{|c|}{ Family Ties } & \multicolumn{3}{|c|}{ Family Ties } \\
\hline & $\begin{array}{l}\text { (1) } \\
\text { All }\end{array}$ & $\begin{array}{c}(2) \\
\text { Weak }\end{array}$ & $\begin{array}{c}(3) \\
\text { Strong }\end{array}$ & $\begin{array}{l}(4) \\
\text { All }\end{array}$ & $\begin{array}{c}(5) \\
\text { Weak }\end{array}$ & $\begin{array}{c}(6) \\
\text { Strong }\end{array}$ \\
\hline \multicolumn{7}{|c|}{ Number of grandparents available } \\
\hline At age 23-25 & $\begin{array}{l}-0.000 \\
(0.009)\end{array}$ & $\begin{array}{l}-0.010 \\
(0.014)\end{array}$ & $\begin{array}{c}0.012 \\
(0.012)\end{array}$ & $\begin{array}{l}-0.015^{* *} \\
(0.007)\end{array}$ & $\begin{array}{l}-0.013 \\
(0.011)\end{array}$ & $\begin{array}{l}-0.013 \\
(0.010)\end{array}$ \\
\hline At age 26-28 & $\begin{array}{c}0.004 \\
(0.009)\end{array}$ & $\begin{array}{l}-0.002 \\
(0.014)\end{array}$ & $\begin{array}{c}0.013 \\
(0.012)\end{array}$ & $\begin{array}{l}-0.010 \\
(0.008)\end{array}$ & $\begin{array}{l}-0.019 * \\
(0.012)\end{array}$ & $\begin{array}{l}-0.001 \\
(0.010)\end{array}$ \\
\hline At age 29-31 & $\begin{array}{l}0.030^{* * *} \\
(0.010)\end{array}$ & $\begin{array}{l}0.018 \\
(0.015)\end{array}$ & $\begin{array}{l}0.047^{* * *} \\
(0.014)\end{array}$ & $\begin{array}{c}0.005 \\
(0.009)\end{array}$ & $\begin{array}{c}0.009 \\
(0.014)\end{array}$ & $\begin{array}{c}0.005 \\
(0.012)\end{array}$ \\
\hline At age 32-34 & $\begin{array}{l}0.033^{* * *} \\
(0.011)\end{array}$ & $\begin{array}{l}0.017 \\
(0.017)\end{array}$ & $\begin{array}{l}0.055^{* * *} \\
(0.015)\end{array}$ & $\begin{array}{c}0.018 \\
(0.011)\end{array}$ & $\begin{array}{c}0.020 \\
(0.017)\end{array}$ & $\begin{array}{c}0.020 \\
(0.015)\end{array}$ \\
\hline At age $35-37$ & $\begin{array}{l}0.026^{* *} \\
(0.012)\end{array}$ & $\begin{array}{c}0.006 \\
(0.019)\end{array}$ & $\begin{array}{l}0.049^{* * *} \\
(0.017)\end{array}$ & $\begin{array}{l}0.032^{* *} \\
(0.013)\end{array}$ & $\begin{array}{c}0.022 \\
(0.019)\end{array}$ & $\begin{array}{l}0.043^{* *} \\
(0.017)\end{array}$ \\
\hline Observations & 35,019 & 16,523 & 18,496 & 35,019 & 16,523 & 18,496 \\
\hline Couples & 4,333 & 2,061 & 2,272 & 4,333 & 2,061 & 2,272 \\
\hline
\end{tabular}

Note. Estimates of equation (3) from the Main Sample by extent of family ties, using the alternative measure of family ties based on the frequency of phone calls with parents, see Section 3 for details. The specification controls for education of head and spouse, age of the male member in the couple, region of residence and regional female employment rate, number of parents alive, parents' age and education, number of siblings of couple's members and a dummy for being the first born male in the family of origin. Standard errors are clustered at the household level. See Section 4 for details. * significant at $10 \%$; ** significant at $5 \%$; *** significant at $1 \%$. 
Figure A.1: Year of birth distribution of members of the family of origin (Main Sample).
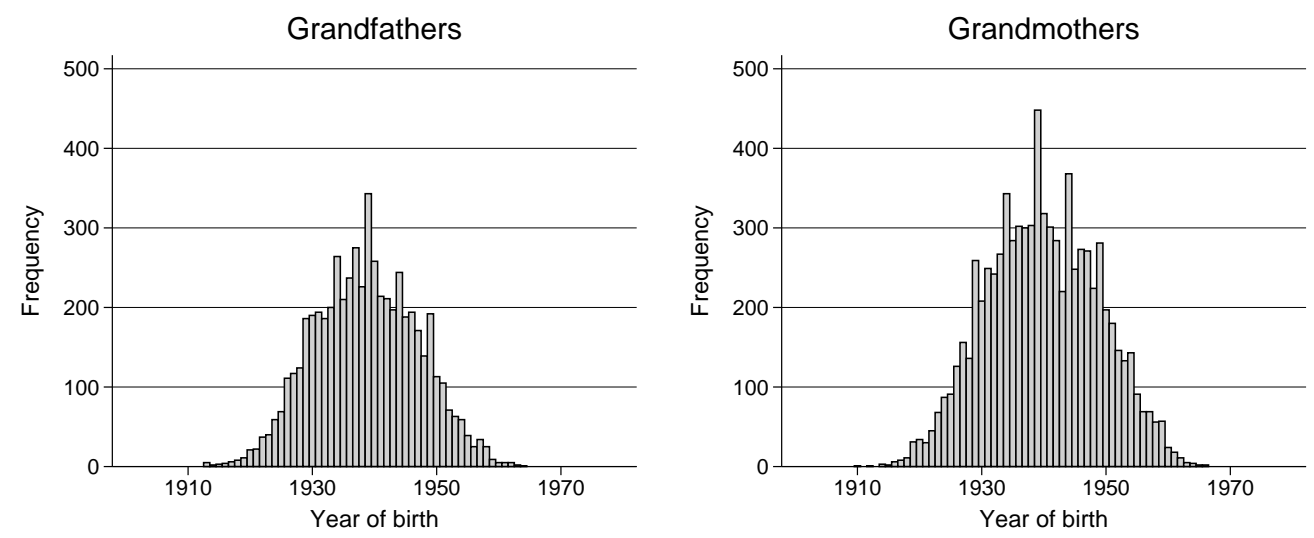

Note. Reported are the distributions of cohorts of grandfathers (left panel) and grandmothers (right panel) as computed from the Main Sample. 
Figure A.2: Family ties across Italian regions (left panel) and their association with female employment rate in 2009 (right panel).
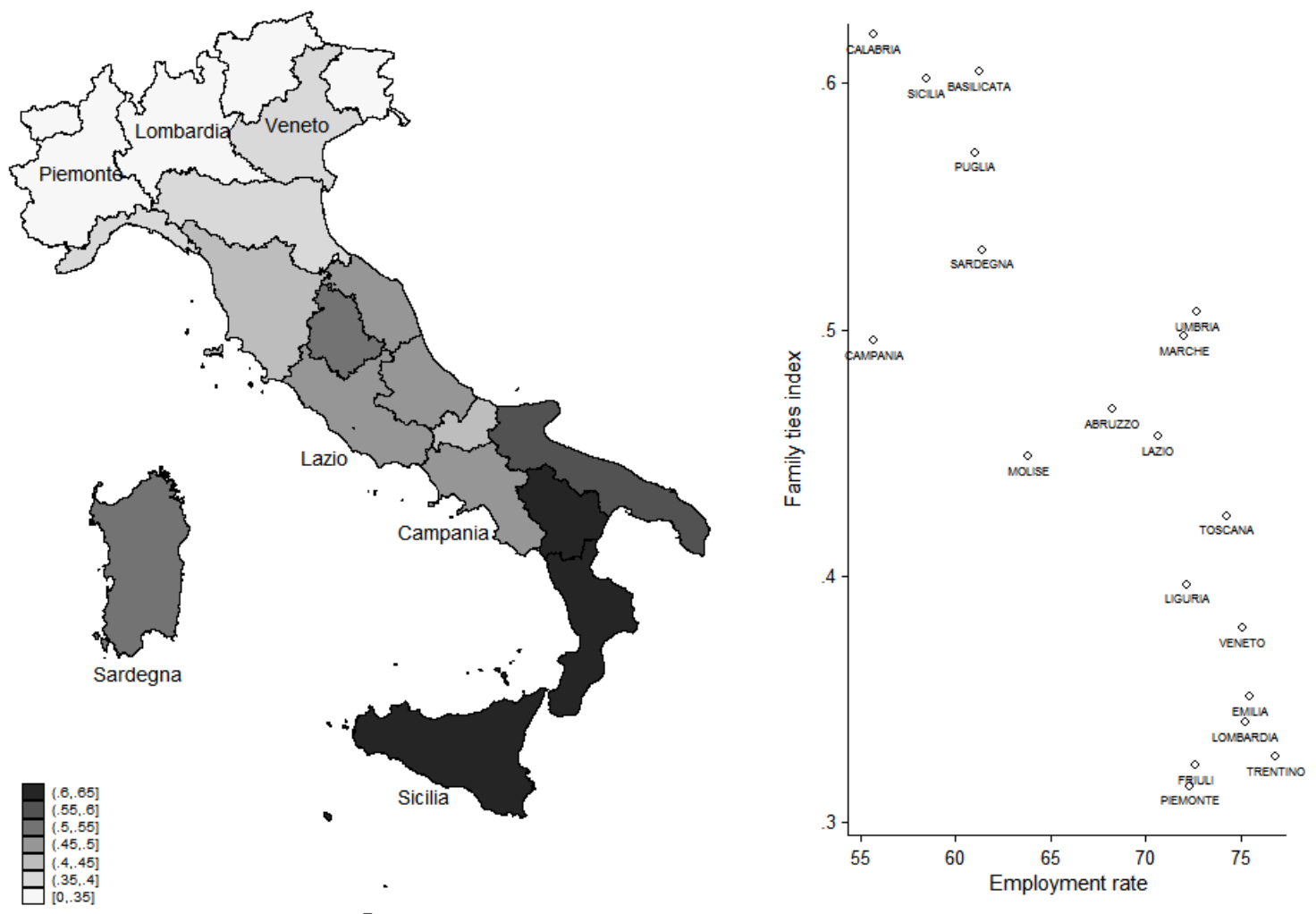

Note. The left panel reports the proportion of couples with strong family ties, see Section 3 for details, by region of residence. The right panel depicts the correlation between the regional proportion of couples with strong family ties and the regional female employment rate in 2009. 
Figure A.3: Kindergarten coverage in 2009 across Italian regions.

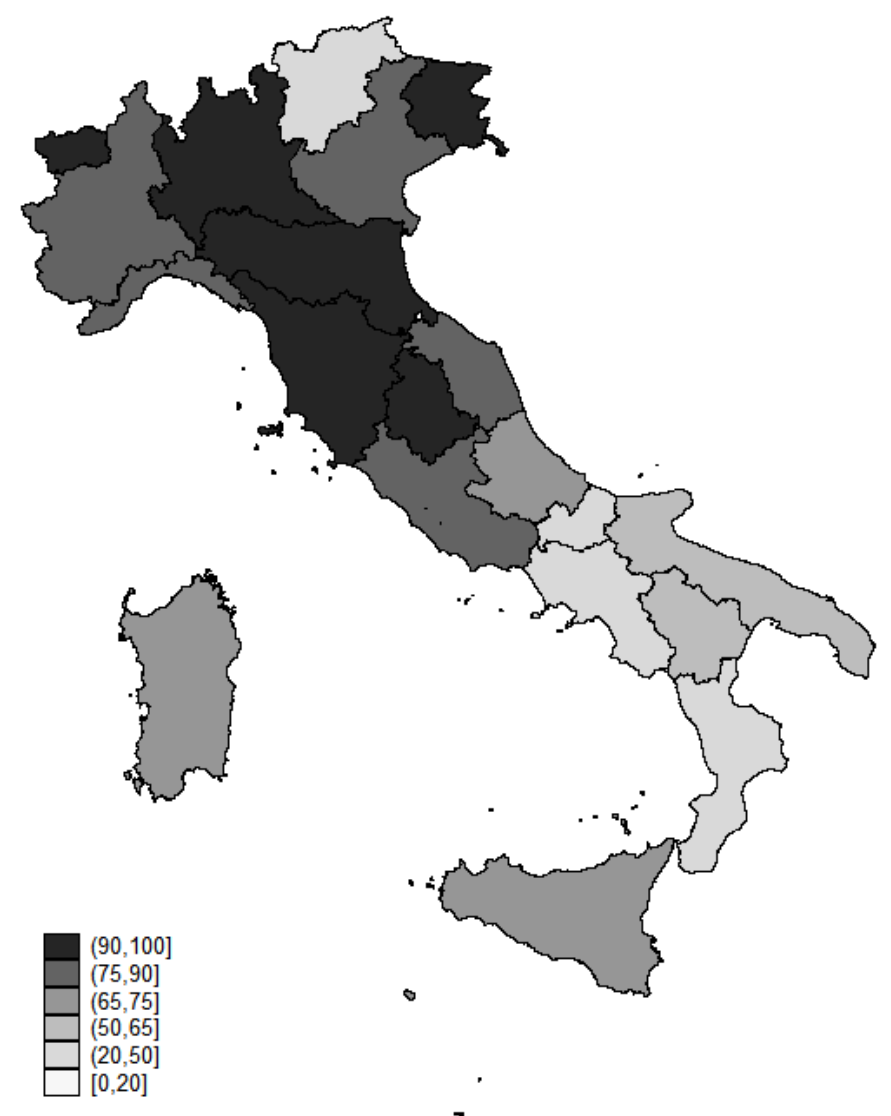

Note. Reported is the geographical distribution of kindergarten coverage in 2009, measured as the proportion of municipalities in the region providing public child-care facilities. 
Figure A.4: Effects of pension reforms on family ties.
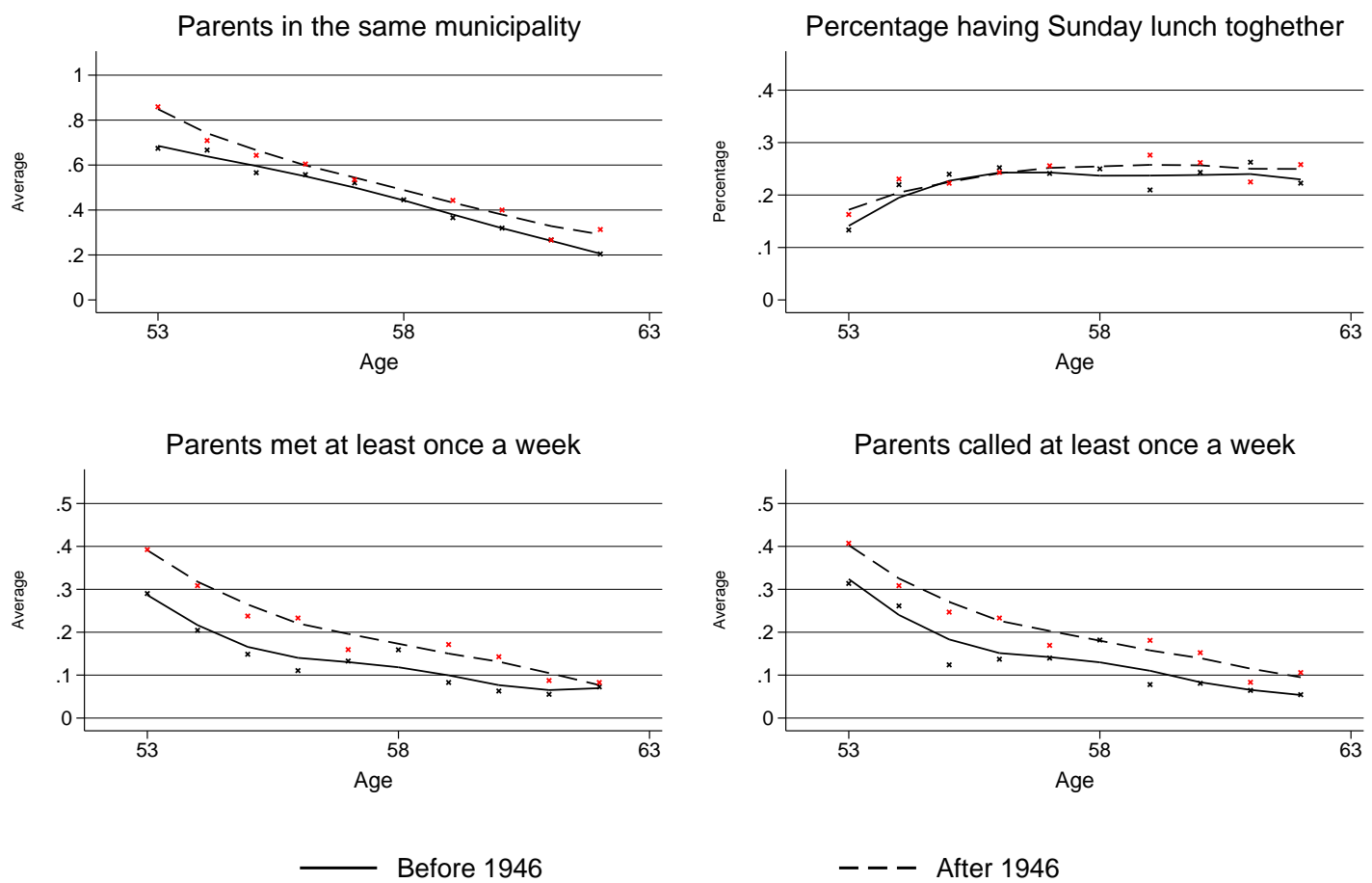

Note. The horizontal axis refers to the age of grandparents. The vertical axis reports the proportion of grandparents living in the same municipality of their children (top left panel); having Sunday lunch with regularly with other members of the family (top right panel), meeting at least once a week with their children (bottom left panel) and calling their children at least once a week (bottom right panel). Figures are obtained by pooling observations from the 1998, 2003 and 2009 waves of the Family and Social Subjects survey, see Section 3 for details. Red dots mark post-1946 cohorts, black dots mark pre-1946 cohorts. Solid and dashed lines are fitted values of non-parametric regressions run over pre and post 1946 cohorts respectively. 
Figure A.5: Extent of misclassification in the definition of homemakers - columns (1) to (6) of Table 8.

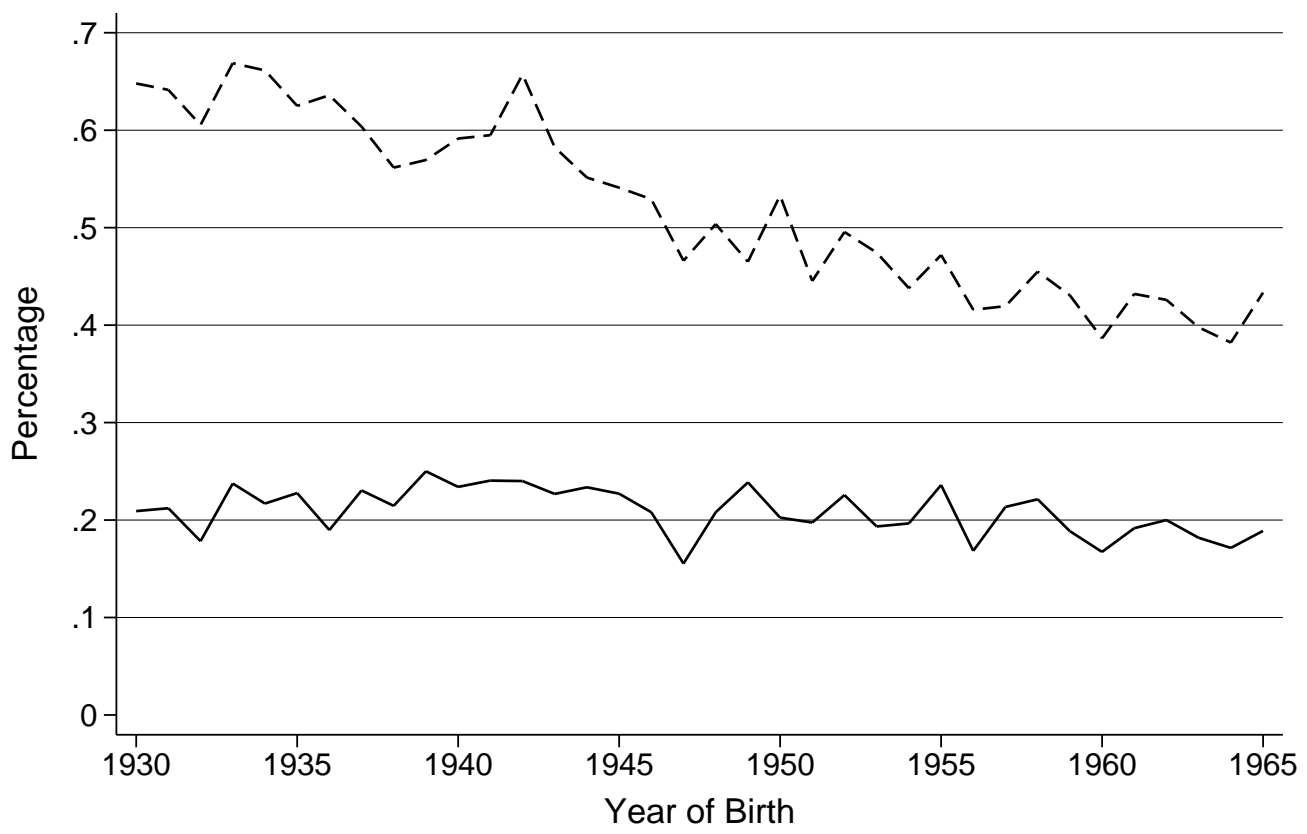

Note. We use data on female respondents, and group them depending on their year of birth which is reported on the horizontal axis. We keep only mothers in 2009, and use retrospective information to select those who were not at work when the first child was aged 10 to 14 . The dashed line in the figure reports the incidence of this group as a fraction of total population in the cohort. We do so to replicate the definition of homemaker employed in columns (1) to (6) of Table 8 , which is derived from the question: 'Think of when you were 14. What was the working status of your mother and your father?'. We define as homemakers those who self-report continuous inactivity in their life at the time of interview. The continuous line in the figure is the percentage of homemakers incorrectly classified using their status when the child was aged 10 to 14 . 